

\title{
BUKU AJAR \\ Inovasi Konselor Sebaya di Sekolah \\ (Dalam Perspektif Pendidikan Islam)
}

\author{
Penulis
}

Eni Fariyatul Fahyuni, S.Psi., M.Pd.I

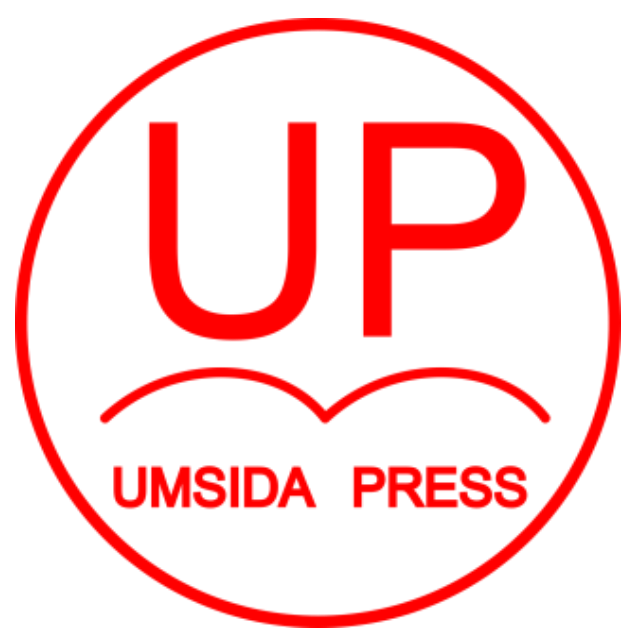

Diterbitkan oleh

UMSIDA PRESS

Jl. Mojopahit 666 B Sidoarjo

ISBN: 978-979-3401-93-5

Copyright@2018.

Authors

All rights reserved 


\section{BUKU AJAR}

Inovasi Konselor Sebaya di Sekolah

(Dalam Perspektif Pendidikan Islam)

\section{Penulis :}

Eni Fariyatul Fahyuni, S.Psi., M.Pd.I

\section{ISBN :}

978-979-3401-93-5

\section{Editor :}

M. Tanzil Multazam

\section{Copy Editor :}

Fika Megawati, S.Pd., M.Pd.

Design Sampul dan Tata Letak :

M. Tanzil Multazam

Penerbit :

UMSIDA Press

\section{Redaksi :}

Universitas Muhammadiyah Sidoarjo

Jl. Mojopahit No 666B

Sidoarjo, Jawa TImur

Cetakan pertama, 29 Maret 2018

(C) Hak cipta dilindungi undang-undang

Dilarang memperbanyak karya tulis ini dengan suatu apapun tanpa ijin tertulis dari penerbit. 


\section{IDENTITAS BUKU}

Inovasi konselor sebaya di sekolah merupakan bagian paling penting dari sebuah layanan pendidikan di sekolah. Untuk mencapai optimalisasi layanan bimbingan dan konseling, sejumlah upaya mesti dilakukan, diantaranya menerapkan berbagai pendekatan (individu, kelompok, dan klasikal), memberdayakan segenap potensi, serta mengembangkan media layanan yang diperlukan guna menyalurkan pesan bimbingan dan konseling yang dapat merangsang pikiran, perasaan, perhatian, dan kemauan siswa/konseli untuk memahami diri, mengarahkan diri, mengambil keputusan serta memecahkan masalah yang dihadapi.

Buku ini disusun dalam rangka merancang dan memfasilitasi calon konselor, konselee, terapis, dan pemerhati profesi konseling mempelajari, mendalami, serta meningkatkan kemampuan mengembangkan dan memanfaatkan media dalam menyelenggarakan layanan bimbingan dan konseling islami di sekolah untuk memahami diri, mengarahkan diri, mengambil keputusan serta memecahkan masalah yang dihadapi. 


\section{Kata Pengantar}

Segala puji hanya milik Allah SWT. Shalawat dan salam selalu tercurahkan kepada Rasulullah SAW. Berkat limpahan dan rahmat-Nya sehingga penulis mampu menyelesaikan buku Inovasi Konselor Sebaya di Sekolah (Dalam Perspektif Pendidikan Islam)" yang tentunya diharapkan dapat memberikan kontribusi positif bagi pembaca dan pemerhati pendidikan khususnya bagi para mahasiswa, guru, calon pendidik maupun dosen mata kuliah Bimbingan dan Konseling.

Sekolah merupakan lembaga formal yang bertujuan mendidik dan mencetak peserta didiknya menuju ke arah perkembangan yang maksimal. Untuk itu diperlukan sistem manajemen yang baik, sistem administrasi yang tertib dan rapi guna memberikan layanan bimbingan dan konseling yang efektif dan efisien. Penulisan buku ini sangat mengharapkan berbagai masukan dan kritik yang bersifat membangun sehingga dapat disempurnakan di masa yang akan datang.

Akhir kata penulis menyampaikan ucapan terima kasih atas motivasi dan bantuan yang diberikan. Mudah-mudahan karya sederhana ini bermanfaat dan dicatat sebagai amal kebajikan di sisiNya. Amin.

Sidoarjo, 18 Februari 2018

Penulis

Eni Fariyatul Fahyuni, S.Psi, M.Pd.I 


\section{DAFTAR ISI}

Cover

Identitas Buku

Kata Pengantar

Daftar isi

Bab I : Bimbingan Konseling di Sekolah

A. Prinsip bimbingan konseling ---------------------------------------- 1

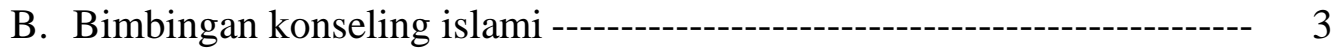

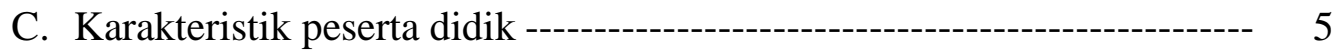

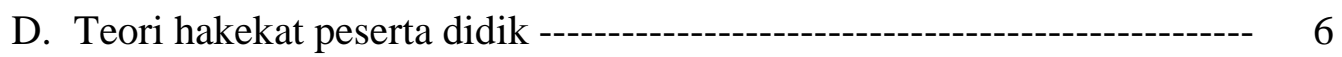

E. Perkembangan peserta didik ------------------------------------------------ 8

F. Karakteristik individu dalam pendidikan ----------------------------------- 10

Bab II : Mengenal Apa Itu Kesulitan Belajar

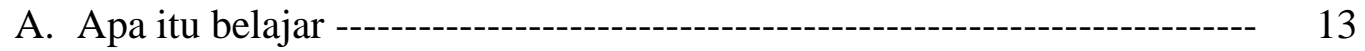

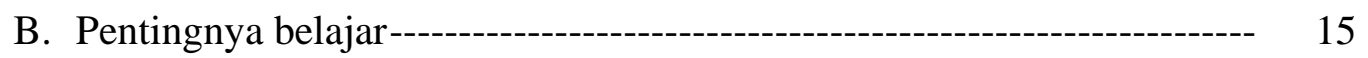

C. Macam-macam aktivitas belajar --------------------------------------------- 17

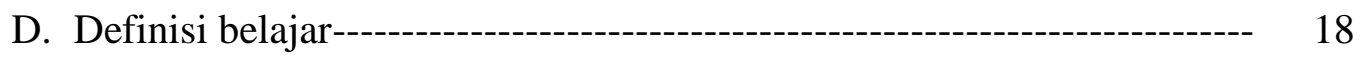

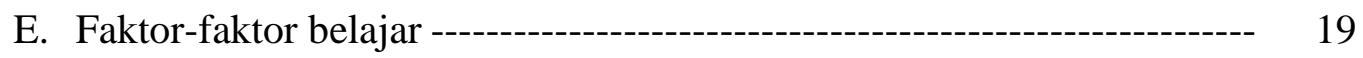

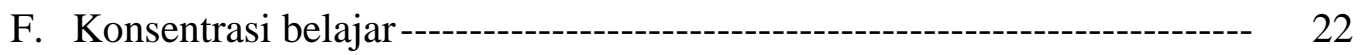

Bab III : Bimbingan Konseling Sebaya

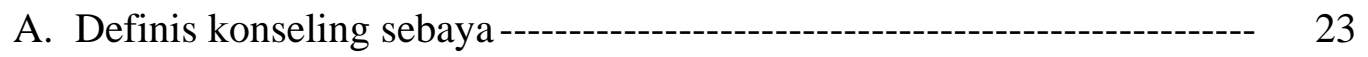

B. Peran teman sebaya -------------------------------------------------------- 25

C. Remaja dan konseling sebaya ------------------------------------------- 27

D. Tahapan pemberdayaan konseling sebaya ------------------------------- 28

E. Tujuan pemberdayaan konseling sebaya---------------------------------- 30 
Bab IV : Pemberdayaan Konseling Sebaya

A. Metode pelaksanaan konseling sebaya ------------------------------------ 31

B. Tahapan pelaksanaan konseling sebaya--------------------------------- 31

C. Penyusunan program bimbingan dan konseling -------------------------- 32

D. Persiapan program bimbingan dan konseling ------------------------- 33

E. Kumpulan instrumen bimbingan dan konseling -------------------------- 38

Lampiran

Daftar Pustaka 


\section{BAB I}

\section{Bimbingan Konseling di Sekolah}

Bimbingan merupakan salah satu unsur di dalam program pendidikan secara keseluruhan, untuk memberikan peran sertanya, agar tercapai makna yang terkandung di dalam bimbingan (Sukardi, 1985). Dengan demikian siswa dapat menikmati serta memberikan sumbangan yang berarti dalam setiap kehidupannya. Bimbingan bukan satu-satunya yang dapat memberikan bantuan dan layanan terhadap individu (siswa), akan tetapi bekerja sama dengan lainnya; seperti layanan sosial, layanan individu dan sebagainya.

\section{A. Prinsip Bimbingan dan Konseling}

Agar dapat melaksanakan pelayanan bimbingan dengan sebaik-baiknya maka ada beberapa hal yang perlu dijadikan pedoman sehingga pelayanan bimbingan dapat sesuai dengan apa yang diharapkan. Adapun prinsip-prinsip bimbingan yang perlu kita pedomani adalah sebagai berikut.

1. Hendaknya dalam memberikan layanan bimbingan individu (siswa) dianggap sebagai individu yang berkemampuan, termasuk kemampuan untuk memecahkan masalahnya. Merupakan tugas pembimbing untuk meningkatkan kemampuan siswa agar menjadi lebih cerdas sehingga dapat memecahkan masalahnya. Dengan berpedoman pada prinsip ini, maka orang yang memberikan nasihat atau menentukan apa yang harus dikerjakan siswa berasal dari kesadaran siswa itu sandiri.

2. Siswa adalah individu yang berharga, sehingga perlu dihormati, sebagaimana keadaannya, mereka (siswa) tidak boleh diremehkan, direndahkan martabatnya, baik oleh sikap perbuatan maupun kata-kata pembimbing. Pembimbing hendaknya menunjukkan sikap hormat kepada klien, menunjukkan perhatian agar klien tambah tumbuh rasa percaya terhadap pembimbing. Perasaan pada proses bimbingan sangat diperlukan. Dengan rasa percaya terhadap pembimbing, siswa mau mengemukakan maslah yang sedang dihadapinya dan tidak menaruh perasaan ragu-ragu, curiga, takut, dan sebagainya.

3. Siswa sebagai individu yang merupakan kebulatan. Tingkah lakunya diwarnai oleh keadaan fisik, psikis, serta sosial dan latar belakang lainnya, demikian pula kelainan tingkah lakunya. Dengan demikian, siswa perlu dipahami oelh pembimbing keadaannya secara menyeluruh, juga segi kehidupannya.

4. Siswa adalah merupakan makhluk unik, artinya antara siswa satu dengan yang lain terdapat perbedaan. Dengan demikian, perlu sekali dipahami sifat-sifat dari masing-masing siswa. Dalam proses pendidikan, peserta didik menjadi pokok 
persoalan dan tumpuan perhatian utama dalam semua proses transformasi pendidikan yang disebut "raw of material" (Fahyuni, E.F \& Istikomah, 2016)

5. Keberhasilan pelayanan bimbingan disekolah amat diperlukan oleh kesediaan serta kesadaran siswa itu sendiri. Tanpa ada kesadaran tersebut layanan bimbingan tidak akan berjalan. Oleh karena itu, usaha paling awal yang perlu dilakukan oleh seorang pembimbing di sekolah adalah menanamkan kesadaran akan pentingnya bimbingan bagi dirinya, setelah itu baru diberi layanan bimbingan.

Istilah bimbingan selalu dirangkaikan dengan istilah konseling. Hal ini disebabkan karena bimbingan dan konseling itu merupakan suatu kegiatan yang integral. Konseling merupakan salah satu teknik dalam pelayanan bimbingan di antara beberapa teknik lainnya, Bimbingan lebih luas, konseling merupakan alat yang paling penting dari usaha pelayanan bimbingan. Konseling merupakan teknik dalam pelayanan bimbingan dimana proses pemberian bantuan itu berlangsung dan tatap muka antara guru pembimbing/konselor dengan klien. Dengan tujuan agar klien itu mampu memperoleh pemahaman yang lebih baik terhadap dirinya, mampu memecahkan masalah yang dihadapinya dan mampu mengarahkan dirinya untuk mengembangkan potensi yang dimiliki ke arah perkembangan yang optimal sehingga ia dapat mencapai kebahagiaan pribadi dan kemanfaatan sosial.

Bimbingan dan konseling memegang tugas dan tanggung jawab yang penting untuk mengembangkan lingkungan, membangun interaksi dinamis antara individu dengan lingkungan, membelajarkan individu untuk mengembangkan, merubah dan memperbaiki perilaku. Berikut ini akan dikemukakan beberapa karakteristik yang terkandung dalam pengertian konseling:

1. Konseling ialah berhubungan dengan usaha mempengarui perubahan sebagian besar tingkah laku klien secara sukarela (klien untuk mengubah dan mendapatkan bantuan dari konselor).

2. Konseling menyajikan perubahan sukarela itu mempelancar dan mempermudah perubahan sukarelaitu (kondisi-kondisi yang demikian itu adalah merupakan kewajiban individu dalam menentukan pilihan yang tepat untuk berdiri sendiri dan memperoleh kepercayaan diri sendiri).

3. Klien mempunyai batas gerak sesuai dengan tujuan konseling yang secara khusus ditetapkan bersama oleh konselor dan klien pada waktu permulaan proses konseling itu (batas gerak itu ditentukan oleh tujuan konseling, yang sebaliknya dipengarui oleh nilai-nilai dan filsafat yang dianut oleh konselor).

4. Kondisi yang mempelancar perubahan tingkah laku itu diselenggarakan melalui wawancara (tidak semua wawancara adalah konseling, tetapi konseling selalu menyangkut wawancara). 
5. Suasana mendengar terjadi dalam konseling, tetapi tidak semua proses konseling itu sendiri dari mendengar itu saja.

6. Konselor memahami klien.

7. Konseling diselenggarakan dalam suasana pribadi dan hasilnya dirahasiakan.

8. Klien mempunyai masalah-masalah psikologis dan konselor memilii keterampilan atau keahlian dalam membantu memecahkan masalah-masalah psikologis yang dihadapi klien.

\section{B. Bimbingan dan Konseling Islami}

Untuk mandapatkan jawaban apa tujuan bimbingan dan konseling Islami itu, terlebih dahulu harus dibahas tentang apa hakekat manusia itu diciptakan (Hallen, 2002). Sebagaimana telah diketahui bahwa Islam memandang bahwa pada hakekatnya manusia itu adalah makhluk Allah yang diciptakan-Nya sebagai khalifah di muka bumi untuk mengabdi kepada-Nya, sebagaimana dalam firman Allah Swt :

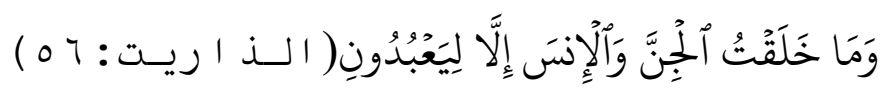

Artinya :

"aku tidak menciptakan jin dan manusia melainkan agar mereka beribadah kepadaKu." (QS. Adz-Dzaariyat /51:56).

Hal ini dipertegas lagi dengan firman Allah Swt.

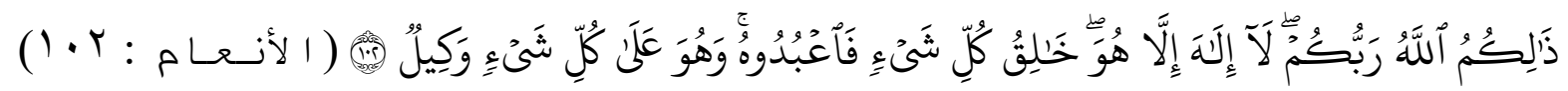

Artinya :

"Itulah Allah, Tuhan kamu; tidak ada Tuhan selain Dia;pencipta segala sesuatu, maka sembahlah Dia...(QS. Al An'am /6:102).

Istilah menyembah (mengabdi) kepada Allah dalam kedua ayat di atas mengandung arti luas. Dengan kata lain istilah menyembah itu bukan hanya mengandung pengertian melaksanakan upacara ritual keagamaan saja, seperti shalat, puasa, zakat, berkorban, haji dan lain sebagainya, tetapi jauh dan lebih luas dari itu.

Menyembah dalam pengertian yang luas adalah bahwa seluruh aktivitas dan tingkah laku yang dilaksanakan seseorang dalam kehidupanya semata-mata mencari keridhaan Allah adalah ibadah, sebagaimana yang termanifestasi dalam do'a yang selalu dibaca dalam setiap melaksanakan shalat. 


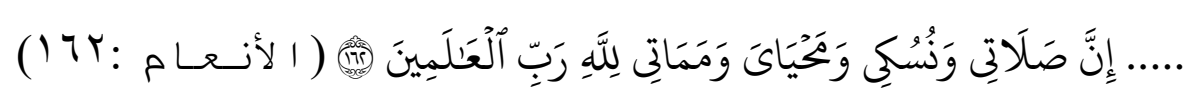

Artinya :

"Sesunguhnya shalatku, ibadahku, hidupku, dan matiku hanyalah untuk Allah, Tuhan seluruh alam."

Implikasi dari pernyataan Allah swt tentang penciptaan dan tujuan hidup manusia diatas dunia ini. Maka dapat dirumuskan tujuan dari pelayanan bimbingan dan konseling Islami yakni untuk meningkatkan dan menumbuh suburkan kesadaran manusia tentang eksistensinya sebagai setiap aktivitas dan tingkah lakunya tidak keluar dari tujuan hidupnya yakni menyembah atau mengabdi kepada Allah. Berbicara tentang obyek dari bimbingan dan konseling Islami, tentu kita harus kembali meneliti dan menghayati bagaimana kondisi manusia pada saat dilahirkan menurut konsepsi Islam (Mu'awanah, E. dan Hidayah, R. 2009). Menurut konsepsi Islam manusia lahir ke dunia dengan dibekali fitrah beragama, sebagaimana dijelaskan oleh Allah Swt dalam firman-Nya :

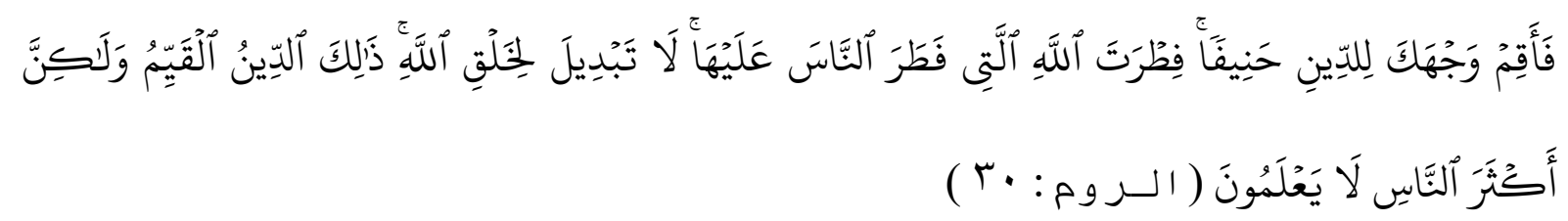

Artinya :

"Maka hadapkanlah wajahmu dengan lurus kepada agama ke agama (Islam); (sesuai) fitrah Allah disebabkan Dia telah menciptakan menusia menurut (fitrah) itu. Tidak ada perubahan pada fitrah Allah. (Itulah) agama yang lurus, tetapi kebanyakan manusia tidak mengetahui “(QS. Ar Ruum /30:30).

Al-Qur'an dan hadist berisikan pedoman tentang sikap dan perilaku yang diridhaiNya dengan sikap dan perilaku yang tidak baik dan tidak disenangi-Nya merupakan faktor potensi eksternal yang akan mempengaruhi perkembangan potensi fitrah beragama yang telah dibawa manusia sejak lahirnya ke dunia.

Dari apa yang dikemukakan di atas, maka dapat diambil kesimpulan bahwa yang dimaksud dengan bimbingan Islami adalah proses pemberian bantuan yang terarah, kontinu dan sistematis kepada setiap individu agar ia dapat mengembangkan potensi atau fitrah beragama yang dimilikinya secara optimal dengan cara menginternalisaikan nilai-nilai yang terkandung di dalam Al-Qur'an dan Hadist Rasullulah ke dalam diri, sehingga ia dapat hidup selaras dan sesuai dengan tuntunan Al-Qur'an dan Hadist. Bila internalisasi nilai-nilai yang terkandung dalam Al Qur'an dan Hadist itu telah tercapai dan fitrah itu telah berkembang secara optimal maka individu tersebut dapat menciptakan hubungan yang baik dengan Allah SWT, dengan manusia dan alam semesta sebagai 
manifestasi dari peranannya sebagai khalifah di muka bumi yang sekaligus juga berfungsi untuk menyembah/mengabdi kepada Allah SWT. Jadi karakteristik manusia yang mempunyai hubungan baik dengan Allah SWT dengan manusia dan alam semesta

\section{Mengenal Karakteristik Peserta Didik}

Secara umum, buku ini mengetengahkan kajian psikologi belajar mengajar yang secara khusus membahas karakteristik perkembangan peserta didik tingkat SD, SMP \& SMA. Aspek-aspek perkembangan yang dibahas dalam buku ini secara garis besarnya meliputi: perkembangan fisik motorik dan otak, perkembangan kognitif, dan perkembangan sosiemosional. Masing-masing aspek perkembangan dihubungkan dengan pendidikan, sehingga para guru diharapkan mampu memberikan layanan pendidikan atau menggunakan strategi pembelajaran yang relevan dengan karateristik perkembangan tersebut.

Dalam proses pendidikan, peserta didik merupakan salah satu komponen manusiawi yang menempati posisi sentral. Peseta didik menjadi pokok persoalan dan tumpuan perhatian dalam semua proses transformasi yang disebut pendidikan. Sebagai salah satu komponen penting dalam sistem pendidikan, peserta didik sering disebut sebagai "raw material". Dalam perspektif pedagogis, peserta didik diartikan sebagai sejenis makhluk "homo educandum", makhluk yang menghajatkan pendidikan. Dalam pengertian ini, peserta didik dipandang sebagai manusia yang memiliki potensi yang bersifat laten, sehingga dibutuhkan binaan dan bimbingan untuk mengaktualisasikannya agar ia dapat menjadi manusia baik yang cakap.

Ditinjau dari perspektif psikologis, peserta didik adalah individu yang sedang berada dalam proses pertumbuhan dan perkembangan, baik fisik maupun psikis menurut fitrahnya masing-masing. Sebagai individu yang tengah tumbuh dan berkembang, peserta didik memerlukan bimbingan dan pengarahan yang konsisten menuju arah titik optimal kemampuan fitrahnya (Arifin, 1996). Dalam perspektif Undang-Undang Sistem Pendidikan Nasional No.20 Tahun 2003 pasal 1 ayat 4 "peserta didik diartikan sebagai anggota masyarakat yang berusaha mengembangkan dirinya melalui proses pendidikan pada jalur jenjang dan jenis pendidikan tertentu."

Berdasarkan beberapa definisi tentang peserta didik yang disebutkan di atas dapat disimpulkan bahwa peserta didik adalah individu yang memiliki sejumlah karakteristik, di antaranya:

1. Peserta didik adalah individu yang memiliki potensi fisik dan psikis yang khas, sehingga ia merupakan insan yang dikembangkan dan diaktualisasikan untuk mencapai taraf perkembangan yang optimal.

2. Peserta didik adalah individu yang sedang berkembang. Artinya peserta didik tengah mengalami perubahan-perubahan dalam dirinya secara wajar, baik yang ditujukan 
kepada diri sendiri maupun yang diarahkan pada penyesuaian dengan lingkungannya.

3. Peserta didik adalah individu yang membutuhkan bimbingan individual dan perlakuan manusiawi.

4. Peserta didik adalah individu yang memiliki kemampuan untuk mandiri. Dalam perkembangannya peserta didik memiliki kemampuan untuk berkembang ke arah kedewasaan dan melepaskan diri dari kebergantungan pada pihak lain. Karena itu, orangtua atau pendidik perlu memberikan kesempatan kepada peserta didik untuk mandiri dan bertanggung jawab sesuai dengan kepribadiannya sendiri.

\section{Teori-teori Hakekat Peserta Didik}

Manusia pada dasarnya membutuhkan pendidikan. Tanpa mendapat pendidikan, manusia tidak akan berkembang dan tidak akan tahu apa-apa. Dalam menciptakan manusia yang berpendidikan atau terdidik, salah satu faktor pendukung utamanya adalah peran seorang guru. Guru adalah orang yang berwenang dan bertanggungjawab untuk membimbing dan membina anak didik, baik secara individual maupun secara klasikal di sekolah dan di luar sekolah.

Sedang peserta didik merupakan komponen manusia yang terpenting dalam proses pendidikan, maka seorang guru dituntut memiliki pemahaman yang mendalam tentang hakikat peserta didik sebagai komponen manusiawi, yakni pemahaman tentang hakikat peserta didik secara umum dalam kajian psikologi terutama tentang bagaimana manusia berkembang dan bertingkah laku, faktor-faktor apa yang mempengaruhi manusia sehingga mampu mendinamisasikan dirinya dalam berbagai perilaku kehidupan.

Belajar yang sesungguhnya tidak menerima begitu saja konsep yang sudah jadi, akan tetapi anak didik harus memahami bagaimana dan darimana konsep tersebut terbentuk, yaitu melalui kegiatan mencoba dan menemukan. Karena belajar berkonotasi pada aktivitas peserta didik, sedangkan aktivitas individu dapat dipengaruhi oleh kondisi emosional, maka sepantasnya suasana pembelajaran harus kondusif dengan keadaan nyaman dan menyenangkan (De Porter, 1992). Itulah tugas seorang guru sebagai pendidik. Dengan suasana yang kondusif, maka muncullah motivasi dan kreativitas. Kondisi inilah sebagai cikal bakal aktivitas belajar aktif, kreatif dan menyenangkan terjadi. Berikut ini akan diuraikan beberapa teori psikologi tentang hakikat peserta didik dalam ruang lingkup pendidikan.

Menurut pandangan psikoanalisis, tingkah laku manusia hanya dapat dipahami melalui pengkajian yang mendalam terhadap ketidaksadaran. Freud menyakini bahwa tingkah laku kita didorong oleh motif-motif di luar alam sadar kita dan konflik-konflik yang tidak kita sadari. Konflik-konflik itu didasari oleh hal-hal di seputar instink-instink atau dorongan-dorongan seksual dan agresif primitif serta kebutuhan mempertahankan implus-implus primitif tersebut di luar kesadaran langsung kita. Jadi, menurut 
pandangan ini, tingkah laku manusia lebih ditentukan dan dikontrol oleh kekuatan psikologis, naluri-naluri irasional yang memang sudah ada sejak semula pada setiap diri individu.

Menurut teori behavioristik, orang terlibat di dalam tingkah laku tertentu karena mereka telah mempelajarinya, melalui pengalaman-pengalaman terdahulu, menghubungkan tingkah laku tersebut dengan hadiah-hadiah. Orang menghentikan tingkah laku, mungkin karena tingkah laku tersebut belum diberi hadiah atau telah mendapat hukuman. Semua tingkah laku, baik bermanfaat ataupun merusak, merupakan tingkah laku yang dipelajari.

Gagasan utama dalam aliran behavioristik ini adalah bahwa untuk memahami tingkah laku manusia diperlukan pendekatan yang objektif, mekanistik dan materialistik, sehingga perubahan tingkah laku pada diri seseorang dapat dilakukan melalui upaya pengkondisian. Dengan perkataan lain, mempelajari tingkah laku seseorang seharusnya dilakukan melalui pengujian dan pengamatan atas tingkah laku yang tampak, bukan dengan mengamati kegiatan bagian dalam tubuh. Menurut Watson, adalah tidak bertanggung jawab dan tidak ilmiah mempelajari tingkah laku manusia semata-mata didasarkan atas kejadian-kejadian subjektif, yakni kejadian-kejadian yang diperkirakan terjadi di dalam pikiran, tetapi tidak dapat diamati dan diukur.

Dalam teori humanistik, manusia digambarkan secara optimistik dan penuh harapan. Di dalam diri manusia terdapat potensi-potensi untuk menjadi sehat dan tumbuh secara kreatif. Manusia digambarkan sebagai individu yang aktif, bertanggung jawab, mempunyai potensi kreatif, bebas, berorientasi ke depan.

Orang-orang yang mengalami pengalaman-pengalaman puncak merasa lebih terintegrasi, lebih bersatu dengan dunia, lebih menjadi raja atas diri mereka sendiri, lebih spontan, kurang menyadari ruang dan waktu, lebih cepat dan mudah menyerap sesuatu, dan sebagainya. Proses pedagogi yang baik harus melibatkan siswa dengan situasi-situasi siswa itu sendiri melakukan eksperimen, yakni siswa mencari tahu apa yang terjadi, memanipulasi benda-benda, memanipulasi simbol-simbol, mengajukan pertanyaan dan berupaya menemukan sendiri jawabannya, mencocokkan apa yang ia temukan di suatu waktu dengan apa yang ia temukan di waktu yang lain, dan membandingkan temuannya dengan temuan siswa lain (Nurdyansyah \& Fahyuni, E.F., 2016)

Sepanjang sejarah kemanusiaan, manusia bertanya, "siapakah aku?". Tradisi keagamaan menjawab dengan menukik jauh ke dalam, "wujud spiritual, ruh". Psikologi modern menjawab dengan menengok ke dalam, self, ego, eksistensi psikologi dan psikoterapi merupakan perjalanan psikologi untuk menemukan diri sendiri. Psikologi transpersonal menghubungkan kedua jawaban ini. Ia mengambil pelajaran dari semua angkatan psikologi dan kearifan menunjuk bahwa di luar alam kesadaran biasa terhadap ragam dimensi lain yang luar biasa potensinya serta mengajarkan praktek-praktek untuk mengantarkan manusia pada kesadaran spiritual, di atas id, ego, dan superego-nya Freud. 
Dari pengertian di atas dapat dipahami bahwa manusia sebagai makhluk individu berarti bahwa manusia itu merupakan keseluruhan atau totalitas yang tidak dapat dibagi. Menurut pengertian ini, maka manusia tidak dipisahkan dari jiwa dan raganya, rohani dan jasmaninya. Manusia tidak terdiri atas penjumlahan dari potensi-potensi tertentu, yang masing-masing bekerja sendiri-sendiri. Kegiatan jiwa dalam kegiatan sehari-hari tidak lain merupakan kegiatan keseluruhan jiwa-raganya, dan bukan kegiatan alat-alat tubuh saja atau kemampuan-kemampuan jiwa saja.

\section{E. Perkembangan Peserta Didik}

Manusia merupakan kesatuan jiwa-badan, maka hanya manusia pula yang merupakan totalitas. Manusia menyadari akan dua momen dalam dirinya sebagai jiwa dan badan, yang kedua-duanya harus selalu menjadi kesatuan yang tak dapat dipisahkan. Kesadaran inilah yang membuat manusia dapat mengadakan refleksi bahwa berkat badan manusia adalah bagian dari alam semesta, tetapi berkat jiwa rohaninya ia melampauinya. Jiwa rohaninya itu membedakan manusia sebagai suatu totalitas dengan segala sesuatu lainnya dalam alam semesta ini.

Semua ini disadari dan dilakukan manusia secara khas sesuai dengan corak kepribadian dan kemampuan masing-masing individu. Oleh karena proses perkembangan dan pengalaman masing-masing individu tidak sama, maka pribadi yang terbentuk dalam proses tersebut juga berbeda antara individu yang atu dengan individu yang lainnya. Realitas ini mengindikasikan bahwa dalam proses perkembangan peserta didik yang wajar harus memperhatikan segi individualitas kemanusiaannya, dalam artinya bahwa setiap individu merupakan kesatuan jiwa raga, yang memiliki struktur dan kecakapan yang unik.

Sesuai dengan sifat individu tersebut, perkembangan peserta didik juga bersifat unik. Dalam hal ini menarik apa yang dikemukakan oleh Saufrock dan Yussen (dalam Rohman Wahab, 1998/1999): "each us develops some other individuals, and like individuals, like some other individuals, and like no other individuals". Jadi, di samping terdapat kesamaan-kesamaan dalam pola-pola umum perkembangan setiap individu, terdapat vanasi individual dalam perkembangan yang bisa terjadi pada setiap saat. Hal ini adalah karena perkembangan itu sendiri merupakan suatu proses perubahan yang kompleks, melibatkan berbagai unsur yang saling berpengaruh satu sama lain.

Setiap anak adalah unik. Ketika kita memperhatikan anak-anak di dalam ruang kelas, kita akan melihat perbedaan individual yang sangat banyak. Bahkan anak-anak dengan latar belakang usia hampir sama, akan memperhatikan penampilan, kemampun, temperamen, minat dan sikap yang sangat beragam.

Dalam kajian psikologi, masalah individu mendapat perhatian yang besar, sehingga melahirkan suatu cabang psikologi yang dikenal dengan individual psychology, atau 
differential psychology, yang memberikan perhatian besar terhadap penelitian tentang perbedaan antar individu. Ini didasarkan atas kenyataan bahwa di dunia ini tidak ada dua orang yang persis sama. Bahkan anak kembar sekalipun masih ditemukan adanya beberapa dimensi perbedaan di antara keduanya.

Secara umum, perbedaan individu terbagi atas dua hal, yaitu perbedaan secara vertikal dan perbedaan secara horisontal. Perbedaan vertikal adalah perbedaan individu dalam aspek jasmaniah, seperti: bentuk, tinggi, besar, kekuatan, dan sebagainya. Sedangkan perbedaan horisontal adalah perbedaan individu dalam aspek mental, seperti tingkat kecerdasan, bakat, minat, ingatan, emosi, temperamen, dan sebagainya. Berikut ini akan diuraikan beberapa aspek perbedaan individual peserta didik tersebut.

\section{Perbedaan fisik-motorik}

Perbedaan individual dalam fisik tidak hanya terbatas pada aspek-aspek yang teramati oleh pancaindra, seperti : bentuk atau tinggi badan, warna kulit, warna mata atau rambut, jenis kelamin, nada suara atau bau keringat, melainkan juga mencakup aspek-aspek fisik yang tidak dapat diamati melalui pancaindra, tetapi hanya dapat diketahui setelah diadakan pengukuran, seperti usia, kekuatan badan atau kecepatan lari, golongan darah, pendengaran, penglihatan, dan sebagainya.

Perbedaan aspek fisik juga dapat dilihat dari kesehatan peserta didik, seperti kesehatan mata dan telinga yang berkaitan langsung dengan penerimaan materi pelajaran di kelas. Dalam hal kesehatan mata misalnya, akan ditemui adanya peserta didik yang mengalami gangguan penglihatan, seperti: rabun jauh, rabun dekat, rabun malam, buta warna, dan sebagainya.

\section{Perbedaan inteligensi}

Intelegensi adalah salah satu kemampuan mental, pikiran atau intelektual dan merupakan bagian dari proses-proses kognitif pada tingkatan yang lebih tinggi. Secara umum inteligensi dapat dipahami sebagai kemampuan untuk beradaptasi dengan situasi yang baru secara cepat dan efektif, kemampuan untuk menggunakan konsep yang abstrak secara efektif, dan kemampuan untuk memahami hubungan dan mempelajarinya dengan cepat.

Dalam proses pendidikan di sekolah, inteligensi diyakini sebagai unsur penting yang sangat menentukan keberhasilan belajar peserta didik. Namun inteligensi merupakan salah satu aspek perbedaan individual yang perlu dicermati. Setiap peserta didik memiliki inteligensi yang berlainan. Ada anak yang memiliki inteligensi tinggi, sedang dan rendah.

Dengan adanya perbedaan individual dalam aspek inteligensi ini, maka guru di sekolah akan mendapati anak dengan kecerdasan yang luar biasa, anak yang mampu memecahkan masalah dengan cepat, mampu berpikir abstrak dan kreatif. Sebaliknya, guru juga akan menghadapi anak-anak yang kurang cerdas, sangat lambat dan bahkan hampir tidak mampu mangatasi suatu masalah yang mudah sekalipun. 


\section{Perbedaan kecakapan bahasa}

Bahasa merupakan salah satu kemampuan individu yang sangat penting dalam proses belajar di sekolah. Kemampuan berbahasa adalah kemampun seseorang untuk menyatakan buah pikirannya dalam bentuk ungkapan kata dan kalimat yang bermakna, logis dan sistematis. Kemampuan berbahasa anak berbeda-beda, ada anak yang dapat berbicara dengan lancar, singkat dan jelas, tetapi ada pula anak yang gagap, berbicara berbelit-belit daan tidak jelas.

Perbedaan individu dalam perkembangan dan kecakapan bahasa anak ini telah menjadi wilayah pengkajian dan penelitian yang menarik bagi sejumlah psikolog dan pendidik. Banyak peneliti eksperimental telah dilakukan untuk menemukan faktorfaktor yang memepengaruhi keberhasilan atau kegagalan dalam penguasan bahasa anak.

Dari sejumlah hasil penelitian tersebut diketahui bahwa faktor nature dan nurture (pembawaan dan lingkungan) sangat mempengaruhi perkembangn bahasa anak. Berhubung faktor-faktor nature dan nurture individu itu bervariasi, maka pengaruhnya terhadap perkembangan bahasa juga bervariasi. Karena itu, tidak heran kalau antara individu yang satu dan individu lainnya berbeda dalam kecakapan bahasanya. Perbedaan kecakapan berbahasa anak ini sangat dipengaruhi oleh berbagai faktor, seperti faktor kecerdasan, pembawaan, lingkungan, fisik, terutama organ bicara, dan sebagainya.

\section{F. Karateristik Individu dan Implikasinya terhadap Pendidikan}

Karateristik individu adalah keseluruan kelakuan dan kemampuaan yang ada pada individu sebagai hasil dari pembawaan dan lingkungannya. Untuk menjelaskan karateristik-karateristik individu, baik dalam hal fisik, mental maupun emosional ini biasanya digunakan istilah nature dan nurture. Nature (alam, sifat dasar) adalah karateristik individu atau sifat khas seseorang yang dibawa sejak kecil atau yang diwarisi sebagai sifat pembawaan, sedangkan nurture adalah faktor-faktor lingkungan yang mempengaruhi individu sejak dari masa pembuahan sampai selanjutnya.

Nature dan nurture ini merupakan dua faktor yang mempengaruhi karateristik individu. Seorang bayi yang baru lahir merupakan hasil dari dua garis keturunan ayah dan ibu. Sejak terjadinya pembuahan atau konsepsi kehidupan, secara berkesinambungan dipengaruhi bermacam-macam faktor lingkungan yang merangsang. Masing-masing perangsang tersebut, baik secara terpisah atau terpadu dengan rangsangan yang lain, semuanya membantu perkembangan potensi-potensi biologis demi terbentuknya tingkah laku manusia yang dibawa sejak lahir.

Pemahaman tentang karateristik individu peserta didik ini memiliki arti penting dalam interaksi belajar-mengajar. Bagi seorang guru khususnya, informasi mengenai karakteristik individu peserta didik ini akan dan sangat berguna dalam memilih dan menentukan pola-pola pengajaran yang lebih baik atau yang lebih tepat, yang dapat menjamin kemudahan belajar bagi setiap peserta didik. Dengan pemahaman atas 
karateristik individu peserta didik ini, guru dapat merekonstruksi dan mengorganisasikan materi pelajaran sedemikian rupa, memilih dan menentukan metode yang lebih tepat, sehingga terjadi proses interaksi dari masing-masing komponen belajar mengajar secara optimal. Di samping itu, pemahaman atas karateristik individu peserta didik juga sangat bermanfaat bagi guru dalam memberikan motivasi dan bimbingan bagi setiap individu peserta didik ke arah keberhasilan belajarnya.

\section{Karateristik Peserta Didik Tingkat SD/MI}

Usia rata-rata anak Indonesia saat masuk sekolah dasar adalah 6 tahun dan selesai pada usia 12 tahun. Kalau mengacu pada pembagian tahapan perkembangan anak, berarti anak usia sekolah berada dalam dua masa perkembangan, yaitu masa kanakkanak tengah (6-9 tahun), dan masa kanak-kanak akhir (10-12 tahun).

Anak-anak usia sekolah ini memiliki karateristik yang berbeda dengan anak-anak yang usianya lebih muda. Ia senang bermain, senang bergerak, senang bekerja dalam kelompok, dan senang merasakan atau melakukan sesuatu secara langsung. Oleh sebab itu, guru hendaknya mengembangkan pebelajaran yang mengandung unsur permainan, mengusahakan siswa berpindah atau bergerak bekerja atau belajar dalam kelompok, serta memberikan kesempatan untuk terlibat langsung dalam pembelajaran. Metode pembelajaran yang paling sesuai pada masa atau periode ini adalah dengan bantuan media konkrit dalam proses pembelajarannya, seperti menggunakan media cerita bergambar (Fahyuni \& Bandono, 2015) dan media komik (Fahyuni \& Fauji, 2017)

Menurut Havighurst (1962), tugas perkembangan anak usia SD/MI meliputi:

a) Menguasai keterampilan fisik yang diperlukan dalam permainan dan aktivitas fisik.

b) Membina hidup sehat.

c) Belajar bergaul dan bekerja dalam kelompok.

d) Belajar menjalankan peranan sosial sesuai dengan jenis kelamin.

e) Belajar membaca, menulis, dan berhitung agar mampu berprestasi dalam masyarakat.

f) Memperoleh sejumlah konsep yang diperlukan untuk berpikir efektif.

g) Mengembangkan kata hati, moral dan nilai-nilai melalui pembelajaran dengan menggunakan media cerita bergambar untuk menanamkan nilai-nilai dan karakter islami pada diri siswa (Fahyuni \& Bandono, 2017).

h) Mencapai kemandirian pribadi.

Dalam upaya pencapaian setiap perkembangan tersebut, guru dalam proses pembelajarannya dituntut untuk memberikan bantuan berupa.

a) Menciptakan lingkungan teman sebaya yang dapat mengajarkan keterampilan fisik.

b) Melaksanakan pembelajaran yang memberikan kesempatan kepada siswa untuk belajar bergaul dan bekerja dengan teman sebaya, sehingga kepribadian sosialnya berkembang. 
c) Mengembangkan kegiatan pembelajaran memberikan pengalaman yang konkret atau langsung dalam membangun konsep.

d) Melaksanakan pembelajaran yang dapat mengembangkan nilai-nilai, sehingga siswa mampu menentukan pilihan yang stabil dan menjadi pegangan bagi dirinya.

\section{Karateristik Peserta Didik Tingkat SMP}

Dilihat dari tahapan perkembangan yang disetujui oleh banyak ahli, anak usia sekolah menengah (SMP) berada pada tahap perkembangan pubertas (10-14 tahun). Terdapat sejumlah karakter yang menonjol pada anak usia SMP ini, yaitu.

a) Terjadi ketidakseimbangan proporsi tinggi dan berat badan.

b) Mulai timbulnya ciri-ciri seks sekunder.

c) Kecenderungan ambivalensi, antara keinginan menyendiri dengan keinginan bergaul, serta keinginan untuk bebas dari dominasi dengan kebutuhan bimbingan dan bantuan dari orangtua.

d) Senang membandingkan kaedah-kaedah, nilai-nilai etika atau norma dengan kenyataan yang terjadi dalam kehidupan orang dewasa.

e) Mulai mempertanyakan secara skeptis mengenai eksistensi dan sifat kemurahan dan keadilan Tuhan.

f) Reaksi dan ekspresi emosi masih labil.

g) Mulai mengembangkan standar dan harapan terhadap perilaku diri sendiri yang sesuai dengan dunia sosial.

h) Kecenderungan minat dan pilihan karier relatif sudah lebih jelas.

Adanya karateristik anak usia SMP yang demikian, maka guru diharapkan untuk:

a) Memberikan kesempatan kepada siswa untuk menyalurkan hobi dan minatnya melalui kegiatan-kegiatan yang positif.

b) Menerapkan pendekatan pembelajaran yang memperhatikan perbedaan individual atau kelompok kecil.

c) Meningkatkan kerja sama dengan orangtua dan masyarakat untuk mengembangkan potensi siswa.

d) Tampil menjadi teladan yang baik bagi siswa.

e) Memberikan kesempatan siswa untuk belajar bertanggung jawab.

\section{Karateristik Peserta Didik Tingkat SMA}

Masa remaja (12-21 tahun) merupakan masa peralihan antara masa kehidupan anak-anak dan masa kehidupan orang dewasa. Masa remaja sering dikenal dengan masa pencarian jati diri (ego identity) ditandai dengan sejumlah karateristik penting, yaitu.

a) Mencapai hubungan yang matang dengan teman sebaya.

b) Dapat menerima dan belajar peran sosial sebagai pria atau wanita dewasa yang dijunjung tinggi oleh masyarakat. 
c) Menerima keadaan fisik dan mampu menggunakannya secara efiktif.

d) Mencapai kemandirian emosional dari orangtua dan orang dewasa lainnya.

e) Memilih dan mempersiapkan karier dari masa depan sesuai dengan minat dan kemampuannya.

f) Mengembangkan sikap positif terhadap pernikahan, hidup berkeluarga dan memiliki anak.

g) Mengembangkan keterampilan intelektual dan konsep-konsep yang diperlukan sebagai warga negara.

h) Mencapai tingkah laku yang bertanggung jawab secara sosial.

i) Memperoleh seperangkat nilai dan sistem etika sebagai pedoman dalam bertingkah laku.

j) Mengembangkan wawasan keagamaan dan meningkatkan religiusitas.

Berbagai karakteristik perkembangan masa remaja tersebut menuntut adanya pelayanan pendidikan yang memenuhi kebutuhannya. Hal ini dapat dilakukan guru, diantaranya:

a) Memberikan pengetahuan dan pemahaman tentang kesehatan reproduksi, bahaya penyimpangan seksual dan penyalahgunaan narkotika

b) Membantu siswa mengembangkan sikapa presiatif terhadap postur tubuh atau kondisi dirinya.

c) Menyediakan fasilitas yang memungkinkan siswa mengembangkan keterampilan yang sesuai dengan minat dan bakatnya.

d) Memberikan pelatihan mengembangkan keterampilan memecahkan masalah dan mengambil keputusan.

e) Melatih siswa mengembangkan resiliensi, kemampuan bertahan dalam kondisi sulit dan penuh godaan.

f) Menerapkan model pembelajaran yang memungkinkan siswa untuk berpikir kritis, reflektif, dan positif.

g) Membantu siswa mengembangkan etos kerja yang tinggi dan sikap wiraswasta.

h) Memupuk semangat keberagaman siswa melalui pembelajaran terbuka dan lebih toleran.

i) Menjalin hubungan yang harmonis dengan siswa, dan bersedia mendengarkan segala keluhan dan problem yang dihadapinya. 


\section{BAB II}

Mengenal Apa Itu Kesulitan Belajar

\section{A. Apa Itu Belajar}

Belajar (learning) adalah salah satu topik paling penting dalam psikologi dewasa ini, namun konsepnya sulit didefinisikan. Amirican Heritage Dictionary mendefinisikannya sebagai berikut: "to gain knowledge, comprehension, or mastery through experience or study" (untuk mendapatkan pengetahuan, pemahaman atau penguasaan melalui pengalaman atau studi). Namun kebanyakan psikolog menganggap definisi ini tidak bisa diterima sebab ada istilah yang samar di dalamnya, seperti pengetahuan, pemahaman dan penguasaan. Sepanjang beberapa tahun belakangan ini terdapat kecenderungan untuk menerima definisi belajar yang merujuk pada perubahan dalam perilaku yang dapat diamati.

Belajar adalah suatu proses usaha yang dilakukan seseorang untuk memperoleh suatu perubahan tingkah laku yang baru secara keseluruhan sebagai hasil pengalamannya sendiri dalam interaksi dengan lingkungannya (Slameto, 2010). Sedangkan menurut Makmun (2007), belajar merupakan suatu proses perubahan perilaku atau pribadi seseorang berdasarkan praktik atau pengalaman tertentu. Senada dengan Skinner dalam Dimyati (2009) berpandangan bahwa belajar adalah suatu perilaku. Pada saat orang belajar maka responsnya menjadi lebih baik. Sebaliknya, bila ia tidak belajar maka responsnya akan menurun. Selain itu, Gagne dalam Rifa'i (2009) menyatakan bahwa belajar merupakan perubahan disposisi atau kecakapan manusia yang berlangsung selama periode waktu tertentu, dan perubahan perilku itu tidak berasal dari proses pertumbuhan.

Kimble (1961) mendefinisikan belajar sebagai perubahan yang relative permanen di dalam behavioral potentiality yang terjadi sebagai akibat dari reinforced practice (praktik yang diperkuat). Meskipun cukup popular, definisi ini tidak diterima secara universal. Pertama, belajar diukur berdasarkan perubahan dalam perilaku, artinya hasil belajar harus selalu diterjemahkan ke dalam bentuk perilaku atau tindakan yang dapat diamati. Kedua, perubahan behavioral relatif permanen artinya hanya sementara dan tidak menetap. Ketiga, perubahan perilaku itu tidak selalu terjadi secara langsung setelah proses belajar selesai. Kendati ada potensi untuk bertindak secara berbeda. Potensi bertindak ini mungkin tidak akan diterjemahkan ke dalam bentuk perilaku secara langsung. Keempat, perubahan perilaku berasal dari pengalaman atau praktik (latihan). Kelima, pangalaman atau latihan harus diperkuat; artinya hanya respon-respon yang menyebabkan penguatlah yang akan dipelajari. 


\section{B. Pentingnya Masalah Belajar}

Masalah mendidik adalah masalah yang dihadapi setiap orang karena setiap individu sejak dahulu hingga sekarang berusaha mendidik anak-anaknya dan atau anakanak lain yang diserahkan kepadanya untuk dididik. Demikian pula masalah belajar dan mengajar yang melekat dalam setiap nafas kehidupan manusia sebagai tindak pelaksanaan usaha pendidikan merupakan permasalahan setiap individu dalam kehidupan sehari-hari. Tiap orang boleh dikatakan selalu belajar sekaligus mengajar, misalnya guru mengajar peserta didiknya, pelatih (coach) mengajar para olahragawan, ibu rumah tangga mengajar pembantu rumah tangga, dokter mengajar pasien-pasiennya cara menjaga kesehatannya, kepala kantor mengajar pegawai-pegawainya.

Kenyataan bahwa "belajar" dan "mengajar" adalah masalah yang dihadapi oleh setiap orang maka perlu dan penting menjelaskan dan merumuskan masalah belajar itu terutama bagi kita kaum pendidik profesional supaya kita dapat menempuhnya dengan lebih efisien dan seefektif mungkin. Belajar pada hakekatnya adalah suatu proses interaksi terhadap semua situasi yang ada di sekitar individu. Belajar dapat dipandang sebagai proses yang diarahkan kepada pencapaian tujuan dan proses berbuat melalui berbagai pengalaman yang diciptakan guru (Hosnan, 2014)

Mengajar harus dikaitkan dengan makna belajar yang perlu menyentuh sejumlah prinsip belajar yang ada pada diri siswa. Oleh karena itu proses pembelajaran memerlukan perwujudan multi peran dari guru, yang bukan hanya menitik beratkan sebagai penyampai pengetahuan dan pengalih ketrampilan, serta merupakan satusatunya sumber belajar, tetapi perlu diubah menjadi pembimbing, pembina, pengajar dan pelatih yang berarti membelajarkan peserta didik. Adapun kegunaan sumber belajar sebenarnya tidak terlepas dari tujuan agar sumber belajar itu menjadi bermakna. Bahan ajar yang pendidik buat harus benar-benar diharapkan mampu membuat peserta didik menguasai kompetensi yang diharapkan (Fahyuni, E.F., 2017)

Beberapa penelitian menemukan bahwa berbagai faktor terkait dengan faktor internal dan faktor eksternal mempengaruhi pembelajaran siswa. Maas (2004) menemukan bahwa kesulitan belajar disebabkan faktor fasilitas yang belum mencukupi terutama buku-buku literatur atau buku paket; anggapan siswa terhadap mata pelajaran; dan kurang memiliki motivasi atau bahkan siswa tidak mengetahui bagaimana metode atau cara belajar yang efektif dan efisien bagi dirinya.

Kesulitan belajar merupakan salah satu permasalahan dalam proses belajar yang ditandai dengan berbagai tingkah laku yang berlatar belakang dalam diri maupun di luar diri si pebelajar (Zakir, 2007). Beberapa tingkah laku tersebut antara lain: menunjukkan hasil belajar yang rendah; hasil yang dicapai tidak seimbang dengan usaha yang telah dilakukan; lambat dalam melakukan tugas-tugas kegiatan belajar; menunjukkan sikapsikap yang kurang wajar; menunjukkan tingkah laku yang berkelainan, seperti membolos, datang terlambat, tidak mengerjakan pekerjaan rumah (PR), mengganggu di 
dalam atau di luar kelas, dan sebagainya; serta menunjukkan gejala emosional yang kurang wajar.

Hasil penelitian Riaz, et al. (2008) menemukan kejelasan pesan yang disampaikan oleh guru; kualitas guru yang terbaik; konsultasi guru di luar kelas mempunyai pengaruh terhadap pembelajaran. Carbone, et al. (2009) menemukan motivasi dan keterampilan teknis yang dimikili berpengaruh terhadap pembelajaran. Kirmani (2008) menemukan faktor akademik, pribadi, media, fasilitas, pelayanan bimbingan, dan iklim organisasi berpengaruh terhadap pembelajaran. Huang (2005) menemukan motivasi ketertarikan paling berefek langsung pada sikap belajar subyek, begitu juga dengan lingkungan sekolah, dan pekerjaan.

\section{Macam-Macam Aktivitas Belajar}

Kalau ditanyakan apakah belajar itu? Maka jawaban yang kita dapatkan akan bermacam-macam. Hal yang demikian ini terutama berakar pada kenyataan bahwa apa yang disebut perbuatan belajar itu adalah bermacam-macam. Banyak aktivitas-aktivitas yang oleh hampir setiap orang dapat disetujui kalau disebut perbuatan belajar, seperti misalnya mendapatkan perbendaharaan kata-kata baru, menghafal syair, menghafal nyanyian, dan sebagainya.

Ada beberapa aktivitas yang tak begitu jelas apakah itu tergolong sebagai perbuatan atau hal belajar seperti misalnya: mendapatkan berbagai macam sikap sosial (misalnya prasangka), kegemaran, pilihan dan lainnya. Selanjutnya ada beberapa hal yang kurang berguna yang juga terbentuk pada individu, seperti misalnya tics, gejalagejala autistis dan sebagainya. Belajar adalah sebuah proses penambahan bagian demi bagian informasi baru terhadap informasi yang telah mereka ketahui dan kuasai sebelumnya. Ini terjadi karena belajar merupakan proses developmental.

Perkembangan kognitif anak terkait dengan kematangan, biologis, psikologis dan sosialnya. Proses belajar terjadi ketika siswa dapat menghubungkan apa yang telah mereka ketahui dengan apa yang mereka temukan dalam pengalaman belajar yang terjadi melalui interaksi yang bermakna antara siswa dengan siswa, guru, bahan pelajaran, dan lingkungan belajarnya. Ini berarti bahwa siswa dapat belajar dengan baik jika mereka mendapat dukungan yang penuh dari orang lain yang memiliki pengetahuan lebih sehingga mereka terbantu dan termudahkan untuk dapat belajar secara mandiri. Dalam perspektif ini, guru berperan sebagai inspirator, fasilitator, director dan scaffolder (Piaget dan Vygotsky, dalam Greedler, 1992).

Gagne, dalam Abdul Majid (2012) menganalogikan belajar merupakan sebuah proses membangun sebuah replika gedung, dimana anak-anak terus-menerus membangun makna baru (pengetahuan, sikap dan ketrampilan) berdasarkan apa yang telah mereka kuasai sebelumnya. Anak atau peserta didik adalah manusia yang membangun. Makna yang terkandung di dalamnya adalah apa yang mereka bangun. Apa 
yang mereka kuasai sebagai modal awal bagi mereka untuk membangun sebuah gedung baru tersebut.

Pembelajaran merupakan faktor yang sangat penting dalam perkembangan kehidupan manusia. Perkembangan merupakan hasil kumulatif dari pembelajaran. menurut Gagne dalam Jauhar (2011) menyatakan bahwa pembelajaran terjadi melalui proses penerimaan informasi, untuk kemudian diolah sehingga menghasilkan keluaran dalam bentuk hasil belajar. Dalam pengolahan informasi terjadi adanya interaksi antara kondisi-kondisi internal dan kondisi-kondisi eksternal individu.

Setiap siswa dalam proses belajarnya memiliki karakteristik yang berbeda dan semangat belajar masing-masing siswa juga berbeda. Dengan perbedaan karakteristik tersebut, maka salah satu solusinya adalah diadakannya metode pembelajaran yang dapat meningkatkan semangat belajar siswa. Proses pembelajaran dapat diikuti dengan baik dan menarik perhatian siswa, apabila menggunakan metode pembelajaran haruslah yang sesuai dengan tingkat perkembangan siswa dan sesuai dengan materi pembelajaran. Hal ini sesuai dengan pilar-pilar belajar yang ada dalam kurikulum pendidikan kita, salah satu pilar belajar adalah belajar untuk membangun dan menemukan jati diri,melalui proses pembelajaran yang aktif, kreatif, efektif, dan menyenangkan (Depdiknas, 2006).

Untuk itu, dalam pembelajaran di sekolah guru harus mampu mengaktifkan siswa selama proses pembelajaran dan mengurangi kecenderungan guru untuk mendominasi proses pembelajaran tersebut, sehingga ada perubahan dalam hal pembelajaran yang berikan yaitu pembelajaran yang berpusat pada guru sudah sewajarnya diubah menjadi berpusat pada siswa.

\section{Macam-Macam Definisi Belajar}

Dalam lingkup pendidikan, belajar diidentikkan dengan proses kegiatan seharihari siswa di sekolah atau di madrasah. Belajar merupakan suatu hal yang sangat kompleks. Kekompleksitasan belajar dapat dipandang dari dua subyek, yaitu siswa dan guru. Dari segi siswa, belajar dialami sebagai suatu proses. Siswa mengalami proses mental dalam menghadapi bahan ajar yang dirancang dan dipersiapkan oleh guru secara khusus untuk pembelajaran ataupun bahan ajar yang ada di alam sekitar yang tidak dirancang secara khusus, tetapi bisa dimanfaatkan oleh siswa untuk belajar. Sedangkan dari sisi guru, belajar itu dapat diamati secara tidak langsung. Artinya proses belajar yang merupakan proses internal siswa tidak dapat diamati tetapi dapat dipahami oleh guru. Proses belajar tersebut nampak melalui perilaku siswa pada tindakan hasil belajarnya, termasuk tindakan belajar berbagai bidang studi di sekolah. Perilaku belajar itu merupakan respon siswa terhadap tindak belajar dan tindak pembelajaran yang dilakukan oleh guru. 
Menurut Ibnu Khaldun dalam Abdul Majid (2012) belajar merupakan suatu proses mentransformasikan nilai-nilai yang diperoleh dari pengalaman yang dimiliki sehingga dapat mempertahankan eksistensinya dalam peradapan masyarakat. Belajar merupakan sebuah proses penambahan bagian demi bagian pengalaman baru yang telah mereka miliki dan kuasai sebelumnya. Senada yang diungkapkan Cronbach di dalam bukunya Educational Psychology mengatakan bahwa: Learning is shown by a change in behavior as a result of experience (Cronbach, 1954, dalam Sumadi, 2013). Belajar yang sebaik-baiknya adalah dengan siswa mengalami; dan dalam mengalami itu siswa mempergunakan panca inderanya.

\section{E. Faktor-faktor yang Mempengaruhi Belajar}

Belajar merupakan suatu proses kompleks yang terjadi pada semua orang yang berlangsung sepanjang masa. Karena kompleksnya masalah belajar banyak sekali teori yang menjelaskan bagaimana proses belajar itu terjadi. Menurut Hamalik (2009) "belajar adalah modifikasi atau memperteguh kelakuan melalui pengalaman (learning is defined as the modification or strengthening of behavior through experiencing)". Dengan kata lain belajar merupakan perubahan yang terjadi pada diri individu sebagai hasil dari pengalaman dirinya dan interaksi dengan lingkungannya. Belajar sebagai proses atau aktivitas disyaratkan oleh banyak sekali faktor-faktor yang mempengaruhinya antara lain.

\section{Faktor-faktor Non-sosial dalam Belajar}

Kelompok faktor-faktor ini boleh dikatakan juga tak terbilang jumlahnya, misalnya: keadaan udara, suhu udara, cuaca, waktu (pagi, siang, ataupun malam), tempat (fasiltas dan kenyaman tempatnya, jaraknya, bising tidaknya dari tempat keramaian dll), alat-alat yang dipakai untuk belajar (alat tulis menulis, buku-buku, alat-alat peraga, dan sebagainya yang biasa kita sebut alat-alat pelajaran).

Faktor-faktor yang mempengaruhi belajar ini harus kita atur sedemikian rupa, sehingga dapat membantu atau menguntungkan proses/perbuatan belajar secara maksimal. Letak sekolah atau tempat belajar misalnya harus memenuhi syarat-syarat seperti di tempat yang tidak terlalu dekat kebisingan atau jalan ramai, lalu bangunan itu harus memenuhi syarat-syarat yang telah ditentukan dalam ilmu kesehatan sekolah. Demikian pula alat-alat pelajaran harus seberapa mungkin diusahakan untuk memenuhi syarat-syarat menurut pertimbangan didaktis, psikologis, pedagogis dan ramah lingkungan.

\section{Faktor-Faktor Sosial dalam Belajar}

Yang dimaksud dengan faktor-faktor sosial adalah faktor manusia (sesama manusia), baik manusia itu ada (hadir) maupun kehadirannya itu dapat disimpulkan. Jadi tidak langsung hadir. Kehadiran orang atau orang-orang lain pada waktu seseorang sedang belajar, banyak kali mengganggu belajar itu; misalnya kalau satu kelas peserta 
didik sedang mengerjakan ujian, lalu terdengar banyak anak-anak lain bercakap-cakap di samping kelas; atau seseorang sedang belajar di kamar, satu atau dua orang hilir mudik keluar masuk kamar belajar itu dan sebagainya. Kecuali kehadiran yang langsung seperti yang telah dikemukakan di atas itu, mungkin juga orang lain itu hadir tidak langsung atau dapat disimpulkan kehadirannya; misalnya saja potret dapat merupakan representasi dari seseorang; suara nyanyian yang sedang dihidangkan lewat radio maupun tape recorder juga dapat merupakan representasi bagi kehadiran seseorang.

Faktor-faktor sosial seperti yang telah dikemukakan di atas itu pada umumnya bersifat mengganggu proses belajar dan prestasi-prestasi belajar. Biasanya faktor-faktor tersebut mengganggu konsentrasi, sehingga perhatian tidak dapat ditujukan kepada hal yang dipelajari atau aktivitas belajar itu semata-mata. Dengan berbagai cara faktor-faktor tersebut harus diatur, supaya belajar dapat berlangsung dengan sebaik-baiknya.

\section{Faktor-faktor Fisiologi dalam Belajar}

Faktor-faktor fisiologis dalam belajar ini dapat dibedakan lagi menjadi 2 macam yaitu:

\section{a. Keadaan tonus jasmani pada umumnya}

Keadaan tonus jasmani individu umumnya dapat melatarbelakangi aktivitas belajar. Keadaan jasmani yang segar akan lain pengaruhnya dengan keadaan jasmani yang kurang sehat atau sedang mengalami gangguan lainnya. Keadaan jasmani yang lelah lain pengaruhnya dengan yang tidak lelah. Dalam hubungan dengan hal ini ada dua hal yang perlu dikemukakan:

1) Nutrisi harus cukup karena kekurangan kadar gizi yang terkandung dalam makanan akan mengakibatkan kurangnya tonus jasmani, yang pengaruhnya dapat berupa kelesuan, lekas mengantuk, lekas lelah, dan sebagainya. Terlebih-lebih bagi anakanak yang masih sangat muda, pengaruh itu besar sekali. Terpenuhinya asupan gizi dan perawatan yang baik merupakan salah satu faktor penentu utama meningkatnya kualitas Sumber Daya Manusia (SDM) (Adisasmito, 2012). Pemberian gizi yang kurang baik terutama terhadap anak-anak, akan menurunkan potensi sumber daya pembangunan masyarakat (Cakrawati \& Mustika, 2012).

2) Beberapa penyakit yang kronis sangat mengganggu belajar itu. Penyakit-penyakit seperti pilek, infuensa, sakit gigi, batuk dan yang sejenis dengan itu biasanya diabaikan karena dipandang tidak cukup serius untuk mendapatkan perhatian dan pengobatan, akan tetapi dalam kenyataannnya penyakit-penyakit semacam ini sangat mengganggu aktivitas belajar itu.

\section{b. Keadaan fungsi panca indera}


Telah dikemukakan bahwa panca indera dapat dimisalkan sebagai pintu gerbang masuknya pengaruh ke dalalm individu. Orang mengenal dunia sekitarnya dan belajar mempergunakan panca inderanya. Baiknya berfungsinya panca indera merupakan syarat belajar berlangsung dengan baik. Dalam sistem persekolahan dewasa ini diantara panca indera itu yang paling memegang peranan dalam belajar adalah mata dan telinga.

Karena itu adalah menjadi kewajiban bagi setiap pendidik untuk menjaga, agar panca indera anak didiknya dapat berfungsi dengan baik, baik penjagaan yang bersifat kuratif maupun yang bersifat preventif, seperti misalnya adanya pemeriksaan dokter secara periodik, penyediaan alat-alat pelajaran serta perlengkapan yang memenuhi syarat, dan penempatan peserta didik-peserta didik secara baik di kelas (pada sekolahsekolah) dan sebagainya.

\section{Faktor-faktor Psikis dalam Belajar}

Ada satu hal yang perlu mendapat perhatian khusus, yaitu hal yang mendorong aktivitas belajar itu merupakan alasan dilakukannya perbuatan belajar. Hal utama yang mendorong sesorang untuk belajar adalah sebagai berikut:

a. Adanya sifat ingin tahu dan ingin menyelidiki dunia yang lebih luas

b. Adanya sifat kreatif manusia dan keinginan untuk selalu maju.

c. Adanya keinginan untuk mendapatkan simpati dari orang tua, guru, dan temanteman

d. Adanya keinginan untuk memperbaiki kegagalan yang lalu dengan usaha yang baru, baik dengan koperasi maupun dengan kompetisi.

e. Adanya keinginan untuk mendapatkan rasa aman bila menguasai pelajaran

f. Adanya ganjaran atau hukuman sebagai akhir daripada belajar. (Sumadi, 2013)

Apa yang telah dikemukakan itu hanyalah sekedar penyebutan sejumlah kebutuhan-kebutuhan saja, yang tentu saja dapat ditambahkan lagi. Kebutuhankebutuhan tersebut tidaklah lepas satu sama lain melainkan sebagai suatu keseluruhan mendorong belajarnya anak. Kompleks kebutuhan-kebutuhan itu sifatnya individual, berbeda dari anak yang satu ke anak yang lainnya. Pendidik seberapa dapat haruslah berusaha mengenal kebutuhan yang mana yang terutama dominan pada anak didiknya.

Seseorang yang akan melibatkan diri dalam suatu aktivitas, terlebih dahulu harus menyadari akan arti dan manfaat aktivitas tersebut bagi dirinya. Dalam pemilihan suatu aktivitas dipengaruhi oleh motivasi yang datang dari dalam dirinya (intrinsik) yang tidak lain merupakan minatnya. Menurut Kamus besar Bahasa Indonesia (Departemen Pendidikan dan Kebudayaan, 2003) minat adalah kecendrungan hati yang tinggi terhadap sesuatu. Menurut Mahmud (2008) minat adalah "Suatu rasa dan suatu ketertarikan pada sesuatu hal, tanpa ada yang menyuruh dan timbul tidak secara tibatiba/spontan, melainkan timbul akibat partisipasi, pengetahuan, dan kebiasaan. Suharsimi (1995) "Anak yang memiliki keingintahuan yang besar akan menanggapi secara positif dan bergairah terhadap pelajaran yang diberikan gurunya". 


\section{F. Konsentrasi Belajar}

Menurut asal katanya, konsentrasi atau concentrate (kata kerja) berarti memusatkan, dan dalam bentuk kata bentuk kata benda, concentration artinya pemusatan. Supriyo (2008) menyatakan konsentrasi adalah pemusatan perhatian pikiran terhadap suatu hal dengan mengesampingkan semua hal lainnya yang tidak berhubungan. Implikasi pengertian di atas berarti pemusatan pikiran terhadap bahan yang dipelajari dengan mengesampingkan semua hal yang tidak ada hubungannya dengan pelajaran tersebut.

Konsentrasi adalah pemusatan pikiran terhadap suatu hal dengan menyampingkan semua hal lainnya yang tidak berhubungan. Dalam belajar konsentrasi berarti pemusatan pikiran terhadap suatu mata pelajaran dengan menyampingkan semua hal lainnya yang tidak berhubungan dengan pelajaran (Slameto, 2010: 86). Selain itu, Siswanto (2007) menyebutkan yang dimaksud konsentrasi yaitu kemampuan untuk memusatkan perhatian secara penuh pada persoalan yang sedang dihadapi. Konsentrasi memungkinkan individu untuk terhindar dari pikiran-pikiran yang mengganggu ketika berusaha untuk memecahkan persoalan yang sedang dihadapi.

Pada kenyataannya, justru banyak individu yang tidak mampu berkonsentrasi ketika menghadapi tekanan. Perhatian mereka malah terpecah-pecah dalam berbagai arus pemikiran yang justru membuat persoalan menjadi semakin kabur dan tidak terarah. Menurut Hakim (2003), secara garis besar, sebagian besar orang memahami pengertian konsentrasi sebagai suatu proses pemusatan pikiran kepada suatu objek tertentu. Dengan adanya pengertian tersebut, timbullah suatu pengertian lain bahwa di dalam melakukan konsentrasi, orang harus berusaha keras agar segenap perhatian panca indera dan pikirannya hanya boleh focus pada satu objek saja. Panca indera, khususnya mata dan telinga tidak boleh terfokus kepada hal-hal lain, pikiran tidak boleh memikirkan dan teringat masalah-masalah lain.

Hasil penelitian Agustina \& Debi M. Yanti (2014) menyatakan bahwa perilaku belajar berpengaruh positif terhadap pemahaman seseorang. Perilaku belajar yang positif akan menimbulkan intensitas kegiatan yang lebih tinggi dibandingkan dengan perilaku belajar yang negatif. Hal ini dapat dilihat dari kebiasaan siswa dalam mengikuti pelajaran dimana dengan perhatian, keaktifan, dan konsentrasi yang baik akan menambah tingkat pemahaman mereka

Konsentrasi bagi setiap orang merupakan suatu proses pemusatan pemikiran kepada suatu objek tertentu. Artinya tindakan atau pekerjaan yang kita lakukan dilakukan secara sungguh-sungguh dengan memusatkan seluruh panca indra kita, penciuman, pendengaran, pengelihatan dan fikiran kita. Konsentrasi ketika mendengar guru menyampaikan materi pastilah harus kita dengar oleh telinga dengan memastikan bahasa dan perintahnya jelas dan pesan itu untuk siapa dan apakah itu perlu di 
sampaikan lagi oleh orang lain apa tidak. Ketika memahami kata perkata tentu harus paham betul arti kata yang di maksud, pendengaran kita harus mampu menyerap apa yang disampaikan guru. Sehingga maksud dan tujuannya sampai.

Jika seorang siswa sering merasa tidak dapat berkonsentrasi di dalam belajar, sangat mungkin ia tidak dapat merasakan nikmat dari proses belajar yang dilakukannya. Hal ini mungkin dapat terjadi karena ia sedang mempelajari pelajaran yang tidak disukai, pelajaran yang dirasakan sulit, pelajaran dari guru yang tidak disukai, atau suasana tempat belajar yang ia pakai tidak menyenangkan (Hakim, 2003).

Gangguan konsentrasi pada saat belajar banyak dialami oleh para pelajar terutama di dalam mempelajari mata pelajaran yang mempunyai tingkat kesulitan cukup tinggi, misalnya pelajaran yang berkaitan dengan ilmu pasti, atau mata pelajaran yang termasuk kelompok ilmu sosial. Kesulitan konsentrasi semakin bertambah berat jika seorang pelajar terpaksa mempelajari pelajaran yang tidak disukainya atau pelajaran tersebut diajarkan oleh pengajar yang juga tidak disukainya.

Kemampuan untuk memusatkan pikiran terhadap suatu hal atau pelajaran itu pada dasarnya ada pada setiap orang, hanya besar kecilnya kemampuan itu berbeda-beda. Hal ini dipengaruhi oleh keadaan orang tersebut, lingkungan dan latihan/pengalaman. Pemusatan pikiran merupakan kebiasaan yang dapat dilatih, jadi bukan bakat/pembawaan. Pemusatan pikiran dapat dicapai dengan mengabaikan atau tidak memikirkan hal-hal lain yang tidak ada hubungannya, jadi hanya memikirkan suatu hal yang dihadapi/dipelajari serta yang ada hubungannya saja.

Selanjutnya agar dapat berkonsentrasi dengan baik perlu dilakukan beberapa usaha misalnya, siswa hendaknya berminat atau punya motivasi yang tinggi untuk belajar, menjaga kesehatan dan memperhatikan kelelahan fisik dan lain sebagainya.

Konsentrasi yang efektif adalah suatu proses terfokusnya perhatian seorang secara maksimal terhadap suatu objek kegiatan yang dilakukannya dan proses tersebut terjadi secara otomatis serta mudah karena orang yang bersangkutan mampu menikmati kegiatan yang sedang dilakukannya. (Hakim, 2003). Terdapat beberapa prinsip konsentrasi yang efektif, diantaranya.

a) Konsentrasi merupakan kemampuan seseorang mengendalikan kemauan, pikiran, dan perasaannya.

b) Untuk mengendalikan kemauan, pikiran, dan perasaan agar tercapai konsentrasi yang efektif dan mudah.

c) Konsentrasi akan terjadi secara otomatis dan mudah jika seseorang telah menikmati kegiatan yang dilakukannya.

d) Salah satu penunjang pertama dan utama untuk dapat melakukan konsentrasi efektif adalah adanya kemauan yang kuat dan konsisten. 
e) Untuk dapat melakukan konsentrasi efektif diperlukan faktor pendukung dari dalam diri orang tersebut (faktor internal) yang meliputi konsisi mental dan fisik yang sehat.

f) Konsentrasi efektif juga baru akan terjadi maksimal jika didukung oleh faktor-faktor yang ada di luar orang tersebut (faktor eksternal), yaitu situasi dan konsisi lingkungan yang menimbulkan rasa aman, nyaman, dan menyenangkan. 


\section{BAB III \\ Bimbingan Konseling Sebaya}

\section{A. Definisi Konseling Sebaya}

Bimbingan konseling sebaya dalam hal ini memiliki tiga aspek pembahasan yakni konsep, implementasi, dan hasil penerapan bimbingan konseling sebaya. Konseling sebaya merupakan tingah laku yang saling membantu serta memperhatikan secara interpersonal diantara teman sebaya, dilakukan oleh individu non-profesional dalam bidang layanan konseling. Bimbingan konseling sebaya berlangsung dalam kehidupan sehari-hari seperti di yang terjadi dilingkungan sekolah.Keterampilan yang dibutuhkan dalam membantu tersebut adalah keterampilan dalam mendengarkan dengan aktif, bersikap empati dan mampu memecahkan masalah. Kedudukan antar individu yang membantu dan yang dibantu adalah setara. Esensinya model konseling sebaya yaitu model konseling yang menggunakan kekuatan pengaruh teman sebaya. Alasannya pengaruh teman sebaya lebih besar dibanding guru maupun orang tua.

Teman sebaya memiliki pengaruh yang besar terhadap perubahan perilaku individu. Teman sebaya juga dapat memberikan penguatan baik itu yang bersifat positif maupun negatif. Konseling sebaya berpotensi akan memberikan penguatan yang bersifat positif, yakni bagaimana seorang teman bisa menjadi motivator teman Lainnya. Implementasi yang dimaksud dalam penelitian ini merupakan pelaksanaan layanan bimbingan konseling sebaya. Konseling sebaya (peer counseling) adalah bantuan konseling yang di berikan oleh teman sebaya yang telah terlebih dahulu diberikan pelatihan untuk menjadi konselor sebaya, sehingga dapat memberikan bantuan baik secara individual maupun kelompok. Bantuan berupa bimbingan diberikan kepada teman-teman yang bermasalah ataupun mengalami berbagai hambatan dalam perkembangan kepribadiannya. Unsur penting dalam konseling sebaya diantaranya, sebagai usaha yang memberikan bantuan yang bersifat interpersonal, dilakukan oleh pihak yang nonprofessional namun dibawah bimbingan professional konselor, dilakukan dalam rentan usia yang relatif sama, dan pelaksanaan dibawah bimbingan konselor ahli.

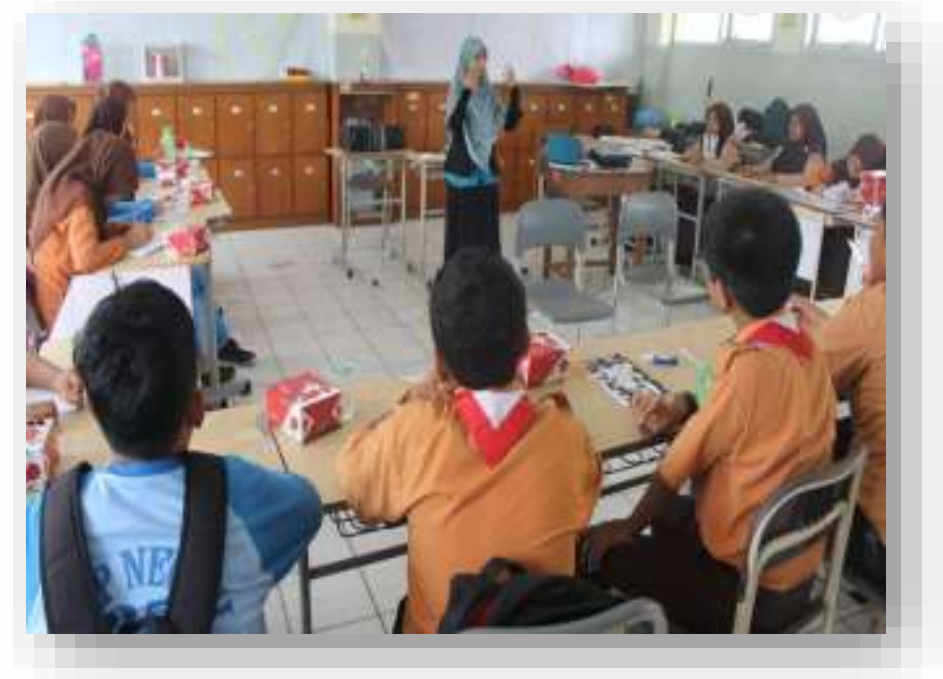

Gambar 3.1 Pemberdayaan konselor sebaya 
Kesimpulan dari penjelasan diatas bahwa konseling sebaya adalah layanan bantuan konseling yang diberikan oleh teman sebaya yang telah terlebih dahulu diberikan pelatihan-pelatihan untuk menjadi konselor teman sebaya. Konselor sebaya dapat memberikan bantuan baik secara individual maupun kelompok kepada seluruh temantemannya yang bermasalah. Terutama individu yang mengalami berbagai hambatan dalam perkembangan kepribadiannya terutama dalam pengembangan sikap prososial.

\section{B. Peran Teman Sebaya}

Teman sebaya adalah siswa dengan tingkat kematangan atau usia yang kurang lebih sama. Konseling sebaya merupakan suatu keterampilan siswa yang berguna untuk mengimplementasikan kemampuan pengontrolan diri dan menghasilkan pengalaman pada remaja. Secara khusus konseling sebaya tidak terfokus pada evaluasi isi, namun lebih fokus pada proses berfikir, proses berasa dan proses pengambilan keputusan. Konseling sebaya merupakan proses pemberian bantuan yang di jembatani oleh siswa lain. Artinya guru bimbingan konseling memilih siswa sebagai relawan yang berperan aktif. Konselor sebaya bukanlah ahli professional konseling namun siswa yang telah dipilih dan diberi pelatihan khusus oleh konselor guna membantu mengentaskan masalah siswa.

Peran dan tanggungjawab seorang konselor sebaya bukanlah sebagai kaki tangan atau intel yang bertugasseperti pengawas, namun berperan sebagai teman baik yang dianggap memiliki kemampuan dan kelebihan-kelebihan yang ada pada diri individu tersebut. Konseling sebaya bertujuan membantu menyelesaikan masalah dan memotivasi teman sebaya. (Hunainah, 2011) menyatakan perlu adanya peningkatan perilaku prososial, karena pada dasarnya berteman bukan hanya sekedar bersama namun berteman yang bisa memberikan peningkatkan perilaku positif. Teman yang baik bukan hanya sekedar tempat bercerita, namun teman yang baik adalah teman yang mampu membantu menyelesaikan masalah dan merasa nyaman, serta mampu membangun motivasi. Motivasi yang dimaksud adalah usaha agar bisa meyakinkan teman agar dapat menumbuhkan tindakan positif tanpa harus memperoleh reward eksternal atau pujian. Berikut ini akan dijelaskan tahapan-tahapan dalam pemberdayaan konseling sebaya di sekolah, antara lain:

\section{Pelaksanaan Konselor Sebaya}

Pelaksanaan konselor sebaya ada empat langkah utama untuk kompetesi peningkatan intrapersonal siswa yaitu

a) Pemilihan dan pelatihan konselor sebaya.

b) Pelaksanaan konseling yang dilakukan oleh konselor sebaya kepada konseli.

c) Konselor sebaya melakukan evaluasi dan follow up dari proses konseling. 
d) Guru bimbingan konseling menindak lanjuti dan mengevaluasi kegiatan konselor sebaya.

\section{Pelatihan kelompok}

Pelatihan dilaksanakan dalam bentuk kelompok dengan beberapa aktivitas sebagai berikut:

a) Menentukan sasaran melalui pengamatan dan pengetahuan terhadap teman-teman kelas yang sedang memiliki masalah.

b) Merencanakan pertemuan untuk kesediaan proses konseling, menentukan waktu, tempat dan lamanya perrtemuan untuk setiap sesinya.

c) Ketika konseling berlangsung konselor sebaya menampilkan keterampilan konseling yang berupa sikap “attending, dengan bersikap positif, menerima kehadiran konseli menghargai, dan sebagainya.

d) Proses konseling berlangsung sampai pada tahap akhir mengevaluasi bersama dan pemecahan masalah.

\section{Evaluasi Konselor Sebaya}

Konselor sebaya melakukan evaluasi dan follow up dari proses bimbingan dan konseling yang dilakukan, melalui:

a) Membuat laporan tertulis terkait pengalaman dan perasaanya menjadi konselor sebaya.

b) Pengamatan terhadap perubahan pada konseli.

c) Berdiskusi tentang perubahan sikap konseli.

d) Konselor sebaya berkonsultasi kepada guru bimbingan konseling. Jika konselor sebaya mengalami kesulitan pemecahan masalah konseli bersedia untuk dialihkan tangan

\section{Tindak Lanjut}

Guru bimbingan dan konseling menindak lanjuti dan mengevaluasi kegiatan konselor sebaya dengan cara yang dilakukannya sebagai berikut:

a) Guru bimbingan konseling meminta konselor sebaya untuk menyampaikan laporan secara tulisan maupun lisan secara berkala misal tiga minggu sekali atau sebulan sekali.

b) Mengamati perubahan yang terjadi pada konseli.

c) Memberikan format isian terkait pengalaman konseli setelah proses konseling selesai, mengisi lembaran format isiam bertujuan untuk memantau kegiatan konseling, mendorong konselor mempraktekkan ilmunya, dan sebagainya. 
Hunainah (2011) mengemukakan pendapat beberapa langkah dalam pelaksanaan bimbingan konseling sebaya diantaranya: a) memberikan kesempatan kepada calon konselor sebaya untuk mempraktekkan layanan konseling yang telah dibekali oleh konselor professional b) melakukan monitoring kepada teman (sebagai konseli) berupa pertemuan atau tatap muka secara langsung secara periodik, artinya mempunyai jadwal tersendiri misalnya dalam seminggu tiga kali pertemuan. c) mendiskusikan kembali kepada konselor ahli yang berperan penting dalam proses konseling. Proses pelaksanaan konseling sebaya merupakan bantuan yang bersifat preventif maupun kuratif. Bersifat preventif jika berhadapan dengan masalah-masalah yang belum terjadi mengkhawatirkan bagi perkembangan peserta didik terutama pada remaja. Bersifat pengobatan jika pernah mengalami masalah-masalah yang beresiko bagi peserta didik.

\section{Remaja dan Konseling Sebaya}

Pelaksanaan bimbingan konseling sebaya bersifat bebas. Artinya bisa diterapkan secara personal maupun kelompok. Hal yang perlu diketahui perbedaan antara konseling sebaya dan konseling remaja. Konseling sebaya merupakan proses pemberian bantuan kepada konseli atau peserta didik dengan dijembatani oleh individu lain yakni yang disebut dengan konselor sebaya. Konseling sebaya dilakukan sesama teman sebaya dengan bimbingan dari profesional konselor atau guru bimbingan konseling, sedangkan konseling remaja merupakan proses konseling yang diberikan secara langsung oleh professional konselor atau guru bimbingan konseling kepada remaja, baik itu remaja awal, tengah maupun akhir.

Salah satu strategi yang dapat digunakan adalah dengan membentuk kelompok konselor sebaya. Hal ini dapat dipahami karena periode remaja merupakan periode yang sangat dekat dengan peer group, membutuhkan pengakuan dari kelompok atau teman sebaya dan membutuhkan identitas baru yang bisa meningkatkan harga dirinya (Hurlock, 2002). Dalam layanan bimbingan dan konseling terhadap berbagai fungsi antara lain (a) Pemahaman, yaitu fungsi untuk membantu peserta didik memahami diri dan lingkungannya, (b) Pencegahan, yaitu fungsi untuk membantu peserta didik mampu mencegah atau menghindarkan diri dari berbagai permasalahan yang dapat menghambat perkembangan dirinya, (c) Pengentasan, yaitu fungsi untuk membantu peserta didik mengatasi masalah yang dialaminya, (d) Pemeliharaan dan pengembangan, yaitu fungsi untuk membantu peserta didik memelihara dan menumbuh-kembangkan berbagai potensi dan kondisi positif yang dimilikinya.

Tujuan dari kegiatan pemberdayaan ini adalah untuk membentuk kelompok konselor sebaya di sekolah yang membantu mensosialisasikan peran dan fungsi bimbingan konseling, meningkatkan kompetensi diri (pribadi yang positif) agar mampu menjadi konselor, membantu memecahkan permasalahan teman sebaya melalui kegiatan konseling. Target yang ingin dicapai dari pelaksanaan kegiatan ini adalah: (a) Remaja 
mempunyai kemampuan dan keterampilan bimbingan dan konseling, (b) Adanya keterlibatan aktif para siswa dalam kegiatan yang dikelola oleh bimbingan dan konseling di sekolah, (c) Berubahnya persepsi dan sikap negatif siswa terhadap lembaga bimbingan dan konseling, (d) Mendorong mitra sekolah untuk mengoptimalkan peran dan fungsi bimbingan dan konseling melalui ketersediaan sumber daya yang dimiliki, (e) Tumbuhnya perilaku positif para siswa yang ditumbuhkan melalui peran sosial secara langsung dalam memecahkan permasalahan teman sebaya.

\section{Tahapan Pemberdayaan Konselor Sebaya}

Tahapan dalam pelaksanaan pemberdayaan konselor sebaya di sekolah adalah melalui beberapa tahapan kegiatan, yaitu:

1. Persiapan.

Tim pengabdian masyarakat mengundang mitra kegiatan untuk mendengarkan penjelasan rencana program atau kegiatan pembentukan kelompok konselor sebaya.

2. Sosialisasi

Tim pengabdian masyarakat menjelaskan tentang berbagai kegiatan yang akan diikuti dan juga berkaitan dengan mekanisme pendaftaran dan membuat kesepakatan dengan mitra masing-masing untuk ikut terlibat secara aktif dalam melakukan pembinaan dan pengawasan kelompok konselor sebaya yang akan terbentuk.

3. Pelatihan dasar

Siswa yang telah terdaftar sebagai calon konselor sebaya akan di assessment dulu tentang motivasi dan karakteristik kepribadiannya serta kemampuan dasarnya sebagai calon konselor, siswa akan diundang mengikuti pelatihan dasar konseling sesuai dengan agenda kegiatan yang telah disepakati, kegiatan pelatihan ini tidak dilakukan dalam satu kali pelatihan tetapi bertahap dengan tujuan terbentuknya kemampuan konseling secara menyeluruh sesuai dengan kebutuhan, semua peserta akan mendapatkan sertifikat mengikuti pelatihan bimbingan dan konseling dan setelah selesai pelatihan para peserta diminta belajar aplikasi di sekolah masingmasing.

4. Pelatihan lanjutan

Tim pengabdian memberikan pelatihan lanjutan dengan fokus pada pembentukan keterampilan dan kemampuan seorang konselor, materi pelatihan akan disesuaikan dengan para siswa di sekolah masingmasing sesuai dengan hasil evaluasi pasca pelatihan dan praktek di lapangan.

5. Pendampingan 
Tim pengabdian mengadakan pendampingan kepada kelompok konselor remaja, kelompok konselor akan diberi kesempatan melakukan kegiatan konseling sebaya di tempat masing-masing.

6. Evaluasi

Tim pengabdian masyarakat bersama-sama dengan mitra mengadakan evaluasi terhadap kegiatan pelatihan dan pendampingan kegiatan, evaluasi juga dilakukan secara bersama-sama dengan kelompok konselor sebaya untuk melihat kemajuan dan penerapan konseling sebaya di masing-masing tempat dan perumusan pengembangan kegiatan dan perluasan kelompok di masa depan.

\section{E. Tujuan Pemberdayaan Konseling Teman Sebaya}

Remaja membutuhkan afeksi dari remaja lainnya, dan membutuhkan kontak fisik yang penuh rasa hormat. Remaja juga membutuhkan perhatian dan rasa nyaman ketika mereka menghadapi masalah, butuh orang yang mau mendengarkan dengan penuh simpati, serius, dan memberikan kesempatan untuk berbagi kesulitan dan perasaan seperti rasa marah, takut, cemas, dan keraguan. Semua hal tersebut dapat difasilitasi melalui konseling teman sebaya. Konseling Teman Sebaya bertujuan membantu dalam:

1. Mengembangkan kemampuan saling memperhatikan dan saling berbagi pengalaman diantara sahabat yang baik.

2. Mengembangkan sikap-sikap positif yang diperlukan sebagai seorang sahabat yang baik.

3. Mengembangkan keterampilan dasar berkomunikasi secara interpersonal yang diperlukan dalam membantu orang lain.

4. Memaknai dan memanfaatkan secara positif kehadiran teman sebaya sebagai salah satu sumber "I Have" resiliensi.

5. Mengembangkan keterampilan dalam menghadapi situasi-situasi sulit yang tidak dapat dihindarkan.

6. Membangun komitmen pribadi terhadap berbagai keputusan yang telah ditetapkan untuk menyongsong kehidupan yang lebih baik. 


\section{BAB IV \\ Pemberdayaan Konselor Sebaya}

\section{A. Metode Pelaksanaan Konselor sebaya}

Kegiatan pemberdayaan konselor sebaya dilakukan melalui berbagai tahapan, diantaranya metode pelatihan dan pendampingan, dimana pelaksanaan kedua metode tesebut dilakukan dengan cara:

1. Metode ceramah

Metode ini mengutamakan pemberian materi tentang peran, fungsi dan manfaat konselor sebaya secara lisan dan tulisan kepada peserta dengan memberikan kesempatan mereka untuk saling berdiskusi dan bertanya terhadap materi yang disampaikan agar terbentuk pemahaman yang sama antara pemateri dan peserta.

2. Role Play

Metode role play merupakan suatu bentuk permainan yang sebelumnya telah dirancang sedemikian rupa dengan disusun dalam suatu skenario untuk memberi kesempatan kepada peserta melakukan suatu peran tertentu sehingga memperoleh pengalaman yang tidak simbolik semata. Didalam role play, peserta didik dituntut mampu menghayati suatu peran tertentu, mencoba dan merasakan menjadi seseorang tertentu dalam suatu proses, sehingga dapat lebih memahami prosesnya dan memiliki gambaran aplikasinya. Dalam kegiatan role play peserta ditempatkan pada situasi menjadi konselor dan konseli untuk mendapatkan pengalaman baru dan nyata tentang proses konseling sebaya.

3. Focused Group Discussion (FGD)

Focused group discussion merupakan suatu teknik diskusi kelompok yang digunakan untuk mendapatkan gambaran dari berbagai pendapat atau opini terhadap permasalahan yang dihadapi. Focused group discussion terdiri atas beberapa peserta dibagi dalam 3 kelompok untuk diminta mengemukakan pendapat-pendapatnya pada suatu masalah tertentu secara terarah, tanpa harus memecahkan masalah tersebut. Dalam waktu antara 30-60 menit peserta diminta mendiskusikan masalah yang sudah dirancang oleh pemateri sehingga peserta mempunyai pemahaman baru tentang berbagai masalah dari berbagai sudut pandang yang berbeda dari setiap permasalahan yang pernah dialami oleh peserta

4. Simulasi, hampir sama dengan role play, tetapi peserta memerankan dirinya sendiri. Didalam simulasi, setting permainannya adalah situasi nyata yang akan dihadapi peserta di masa yang akan datang. Seorang peserta diminta melakukan sesuatu yang benar-benar akan dilakukannya dalam waktu dekat (memerankan dirinya sendiri), sementara peserta yang lain memainkan peran sebagai orang lain yang nanti akan terlibat dalam proses yang disimulasikan itu. 


\section{B. Tahapan Pelaksanaan Konselor Sebaya}

Tahapan pelaksanaan kegiatan pemberdayaan konselor sebaya di sekolah ini dibagi dalam beberapa tahap yaitu.

1. Tahap persiapan

Tahap ini diawali oleh tim pengabdian masyarakat dengan mengundang beberapa mitra kegiatan untuk mendengarkan penjelasan rencana program atau kegiatan pembentukan kelompok konselor sebaya. Mitra yang dimaksudkan dalam hal ini adalah guru BK, wakasek kurikulum, kepala sekolah, serta siswa sebagai konselor sebaya yang akan diberdayakan. Kegiatan pada tahap persiapan ini memerlukan waktu yang lebih lama dalam pelaksanaannya untuk menjamin tingkat kesuksesan seluruh program yang dicanangkan. Adapun persiapan yang dilakukan meliputi : (a) melakukan sosialisasi terhadap mitra kegiatan untuk memastikan keberlangsungan kegiatan ini dengan mengungkapkan time schedule diawal dan hal-hal yang menjadi konsekuensi kegiatan tersebut, (b) melakukan koordinasi dan TOT (training for trainer) tentang pentingnya pelatihan konseling sebaya kepada tim mahasiswa yang akan membantu program pengabdian ini secara berkelanjutan. Tim mempersiapkan 8 mahasiswa untuk menjadi trainer dan pendamping kegiatan konseling sebaya, (c) mempersiapkan materi pelatihan dan pembuatan buku panduan pemberdayaan konselor sebaya yang akan diberikan kepada seluruh peserta dan mitra kegiatan.

2. Tahap sosialisasi

Tahap selanjutnya adalah tim pengabdian masyarakat menjelaskan tentang berbagai kegiatan yang akan diikuti dan juga berkaitan dengan mekanisme pendaftaran dan membuat kesepakatan dengan mitra masing-masing untuk ikut terlibat secara aktif dalam melakukan pembinaan dan pengawasan kelompok konselor sebaya yang akan terbentuk guna mereka dapat mengembangkan sikap-sikap positif peserta didik lainnya yang diperlukan untuk membantunya keluar dari berbagai persoalan yang membelitnya sebagai seorang sahabat yang baik.

3. Tahap pelatihan dasar.

Pada tahap ini, siswa yang telah terdaftar sebagai calon konselor sebaya akan di assessment (penilaian) tentang kemampuan akademik, motivasi dan karakteristik kepribadiannya, serta kemampuan dasarnya sebagai calon konselor. selanjutnya siswa akan diundang mengikuti pelatihan dasar konseling sesuai dengan agenda kegiatan yang telah disepakati, kegiatan pelatihan ini tidak dilakukan dalam satu kali pelatihan tetapi bertahap hingga terbentuknya kemampuan konseling secara menyeluruh sesuai yang diharapkan diawal. Semua peserta didik yang terlibat sebagi konselor sebaya akan mendapatkan sertifikat mengikuti pelatihan bimbingan dan konseling dan setelah selesai pelatihan para peserta diminta belajar aplikasi di sekolah atau di kelas, bahkan dengan teman terdekatnya masing- masing. Tujuan dari kegiatan pelatihan dasar ini adalah : (a) memperkenalkan program konseling 
sebaya sebagai alternatif pemecahan masalah bagi siswa, (b) memberikan pengetahuan dan pemahaman tentang proses konseling sebaya, (c) membentuk karakteristik dasar seorang konselor sebaya, (d) meningkatkan kepekaan terhadap lingkungan sekitar, (e) membantu pengurus panti asuhan dalam mengelola berbagai permasalahan yang ada di tempat tersebut melalui program konseling sebaya.

4. Tahap pelatihan lanjutan

Pada tahap ini, tim pengabdian masyarakat memberikan pelatihan lanjutan dengan fokus pada pembentukan keterampilan dan kemampuan siswa sebagai seorang konselor yang cakap dan mumpuni. Materi pelatihan akan disesuaikan dengan kondisi, kemampuan siswa di sekolah masing-masing sesuai dengan hasil evaluasi pasca pelatihan dan praktek di lapangan. Sesuai dengan tujuan dilakukannya kegiatan pengabdian masyarakat ini dan hasil evaluasi dari pelatihan dasar konseling sebaya, maka dibutuhkan adanya pelatihan lanjutan. Kegiatan ini bertujuan untuk (a) meningkatkan kompetensi dan keterampilan peserta dalam kegiatan konseling sebaya, (b) membentuk konselor sebaya yang sesuai dengan kebutuhan program konseling, (c) menyebarluaskan teknik konseling sebaya sebagai salah satu alternatif pemecahan masalah bagi remaja.

5. Tahap pendampingan.

Pada tahap ini, tim pengabdian masyarakat mengadakan pendampingan kepada beberapa kelompok konselor remaja dan kelompok konselordi sekolah yang terpilih dan akan diberi kesempatan melakukan kegiatan konseling sebaya di tempat masingmasing. Program pendampingan untuk memastikan bahwa peserta melakukan kegiatan konseling dan memiliki kemampuan dasar yang dibutuhkan saat melakukan konseling sebaya. Kegiatan pendampingan ini juga berfungsi untuk menjembatani informasi terbaru berkaitan dengan permasalahan yang dihadapi oleh teman-teman sebayanya dan permasalahan individual.

6. Tahap evaluasi.

Pada tahap ini, tim pengabdian masyarakat bersama-sama dengan mitra mengadakan evaluasi terhadap kegiatan pelatihan dan pendampingan kegiatan konselor sebaya di sekolah masing-masing. Evaluasi juga dilakukan secara bersamasama dengan kelompok konselor sebaya untuk melihat kemajuan perkembanan pemberdayaan yang telah dilakukan dan penerapan konseling sebaya di masingmasing tempat guna perumusan pengembangan kegiatan dan perluasan konselor sebaya yang lebih efektif dan maksimal peran dan tanggungjawabnya di masa depan 


\section{Penyusunan Program BK}

Kegiatan penyusunan program bimbingan dan konseling di sekolah adalah merupakan seperangkat kegiatan yang dilakukan melalui berbagai bentuk survei untuk menginventarisasi tujuan, kebutuhan, kemampuan sekolah serta persiapan sekolah untuk melaksanakan program bimbingan konseling. Tahap persiapan penyusunan program ini mempunyai arti yang penting untuk menarik perhatian dan minat dalam kegiatan bimbingan konseling di sekolah, serta menentukan tolak ukur program bimbingan konseling di sekolah. Juga memelihara suasana psikologis Juga memelihara suasana psikologis yang menguntungkan, karena semua pihak terlibat di dalamnya untuk ikut serta secara aktif berpartisipasi sejak awal kegiatan dalam persiapan penyusunan program.

Dengan demikian dapatlah dikatakan bahwa tahap persiapan adalah merupakan seperangkat kegiatan mengumpulkan berbagai hal yang dibutuhkan untuk penyusunan program dan pengadaan kelengkapannya. Dalam tahap persiapan penyusunan program bimbingan konseling ini, butir-butir kegiatan yang dilakukan dapat dirinci sebagai berikut :

\section{Persiapan Program BK}

\section{Studi Kelayakan}

Studi kelayakan adalah merupakan seperngkat kegiatan dalam pengumpulan berbagai informasi tentang hal-hal yang dibutuhkan untuk penyusunan program bimbingan konseling di sekolah. Dengan adanya studi kelayakan ini, kesimpulan dan saran-saran yang sajikan pada akhir studi dipakai sebagai tolak ukur untuk menentukan program bimbingan konseling yang perlu diperbangkan di sekolah. Dalam studi kelayakan yang dapat di pertimbangkan ialah beberapa aspek, di antarnaya : (1). sasaran dan prasarana, yang kemungkinan bisa untuk digali, (2). pengendalian pelaksanaan program, (3). pembiayaan kegiatan secara keseluruhan yang menunjang pelaksanaan program, dan berbagai aspek lainnya yang bisa digali.

Dari hasil pengkajian aspek-aspek tersebut, beberapa kemungkinan yang akan diambil sebagai kesimpulan bahwa: (1) suatu kegiatan sangat layak untuk untuk dilaksanakan, (2) suatu kegiatan layak untuk dilaksanakan, (3) kegiatan kurang layak untuk dilaksanakan, (4) kegiatan tidak layak untuk dilaksanakan.

\section{Penyusunan Program BK}


Dalam tahap penyusunan program hendaknya perlu diperhatikan beberapa pertimbangan, di antaranya:

a. Siswa baik yang berkenaan dengan masalah pribadi, emosial, hubungan sosial, keluarga, pendidikan, pilihan pekerjaan, jabatan atau karier.

b. Guru pembimbing, dalam pelaksanaan bimbingan konseling di sekolah, baik yang berkenaan dengan jelas jenis layanan, maupun proses pengolahan bimbingan dan penyuluhan di sekolah.

c. Kepala sekolah, dalam proses pengolahan bimbingan konseling di sekolah yang berkaitan dengan program, organisasi, kepemimpinan, maupun segi pembinaan.

Dalam penyusunan program bimbingan konseling hendaknya dirumuskan dengan jelas tujuan yang ingin dicapai dalam menangani berbagai masalah, serta dirumuskan bentuk-bentuk kegiatan yang berkenaan dengan butir dan sub butir rincian kegiatan waktu pelaksanaan, dan sasarannya. Dalam penyusunan program bimbingan konseling di sekolah hendaknya dirumuskan dan invenarisasikan berbagi fasilitas yang ada, termasuk di dalamnya personil bimbingan yang telah ada sebagai penopang pelaksanaan program bimbingan dan penyuluhan di sekolah, serta anggaran biaya yang diperlukan memperlancar jalanya kegiatan bimbingan dan penyuluhan sekolah.

Dengan memperhatikan hal-hal tersebut di atas dapatlah dikatakan di sekolah adalah merupakan seperangkat kegiatan merumuskan masalah dan tujuan, bentukbentuk kegiatan, personil, fasilitas, anggaran biaya yang diperlukan, serta berbagai bentuk usulan kegiatan yang akan dilaksanakan dalam jangka waktu tertentu.

\section{Konsultasi Usulan Program BK}

Dalam kegiatan konsultasi adalah berupa pertemuan atau guru bimbingan dan petugas lain yang terkait untuk membahas usul atau rancangan program bimbingan dan penyuluhan. Beberapa kegiatan yang bisa dilakukan sebagaimana dikemukakan terdahulu adalah sebagai berikut :

a. Pertemuan awal

Tujuan utama dari pertemuan ini adalah untuk menanamkan pengertian bagi para peserta pertemuan (guru pembimbing, kelas, guru mata pelajaran), staf administrasdi bimbingan dan lainnya) tentang pertemuan ini melibatkan petugaspetugas terkait, yang berminat dan tertarik, serta memiliki kemampuan dalam bidang bimbingan konseling.

b. Pembentukan panitia sementara

Kegiatan ini adalah bertujuan untuk merumuskan program bimbingan. Tugas-tugas dari panitia sementara ini ialah mencakup tugas menentukan program bimbingan, rincian kegiatan, mempersiapkan bagan atau pola organisasi dari program bimbingan serta membuat kerangka dasr dari program bimbingan konseling.

c. Pembentukan panitia penyenggara 
Terbentuknya panitia penyenggara bimbingan konseling ini, selanjutnya mempunyai tugas-tugas diantaranya: mempersiapkan pelaksanaan program layanan bimbingan konseling, mempersiapkan pelaksanaan sistem pencatatan, dan mempersiapkan pelaksanaan pelatihan bagi para pelaksanaan program bimbingan.

\section{Penyediaan Fasilitas}

Fasilitas yang dimaksud di sini adalah fasilitas dan teknis. Kedua fasilitas ini merupakan faktor yang sangat menentukan dalam pelaksanaan program bimbingan konseling di sekolah. Fasilitas yang perlu disediakan di antaranya :

4.1. Fasilitas fisik

1) ruang bimbing dan penyuluhan

a. ruang kerja penyuluh.

b. ruang pertemuan

c. ruang administrasi/tata usaha bimbingan.

d. ruang penyimpanan data/catatan-catatan.

e. ruang tunggu.

2) Alat-alat perlengkapan ruangan

a. meja dan kursi-kursi

b. tempat penyimpanan catatan-catatan (locker, almari, rak dan sebagainya.)

c. papan tulis dan papan pengumuman.

4.2. Fasilitas teknis

Fasilitas teknis yang dimaksud adalah alat-alat pengumpul data seperti : angket, tes, inventory, daftar cek.

\section{Penyediaan Anggaran Biaya}

Untuk kelancaran program bimbingan perlu disediakan anggaran biaya yang memadai untuk biaya-biaya dalam pos sebagai berikut :

a. Pembiayaan personal

b. Pengandaan dan pengembangan alat-alat teknis

c. Biaya operasional

d. Biaya penelitian atau riset

\section{Pengorganisasian $\mathrm{BK}$}

Untuk mencapai tujuan yang optimal dalam pelaksanaan program bimbingan konseling di sekolah, maka diperlukan pengorganisasian kegiatan layanan bimbingan yang baik. Pengorganisasian dalam pengertian umun berarti suatu bentuk kegiatan yang 
mengatur cara kerja, prosedur kerja, dan pola kerja atau mekanisme kerja kegiatan layanan bimbingan konseling. Bimbingan konseling tidak dapat dilaksanakan secara berdaya guna dan berhasil guna kalau tidak diimbangi dengan organisasi yang baik. Tanpa oganisasi, itu berarti tidak adanya suatu koordinasi, perencanaan, sasaran, yang cukup jelas, kontrok, serta kepemimpinan yang berwibawa, tegas dan bijaksana.

Agar pengorganisasian kegiatan bimbingan konseling dapat mengkoordinasikan kegiatan-kegiatan bimbingan konseling yang baik, di sekolah, maka beberapa hal yang perlu diperhatikan di antaranya :

a. Semua personel sekolah, meliputi kepala sekolah, koordinator bimbingan, guru pembimbing, guru mata pelajaran, wali kelas, dan staf administrasi bimbingan harus dihimpun dalam satu wadah, sehingga terwujut satu kesatuan cara bertindak dalam usaha membantu memberikan layanan bimbingan dan penyuluhan di sekolah

b. Mekanisme kerja, pola kerja, atau prosedur kerja bimbingan konseling di sekolah harus tuggal, sehingga para siswa tidak menjadi bingung karena adanya berbagai bentuk layanan bimbingan atau layanan lain yang serupa yang dilaksanakan oleh petugas-petugas yang berbeda.

c. Tugas-tugas, tanggung jawab dan wewenang dari masing-masing petugas yang terlibat dalam pelaksanaan layanan bimbingan di sekolah harus dirinci dalam pelaksanaan layanan bimbingan di sekolah harus dirinci dengan jelas, sehingga masing-masing petugas bimbingan akan dapat memahami dan mengerti kewajiban dan tanggung jawabnya masing-masing.

Kriteria penilaian keberhasilan program bimbingan dan penyuluhan di sekolah didasarkan atas :

a. Ada tidaknya jenis program :

1) Bimbingan pribadi

2) Bimbingan emosional

3) Bimbingan sosial

4) Bimbingan belajar

5) Bimbingan jabatan atau karier.

b. Ketepatan program yang memeng dibutuhkan oleh siswadalam sekolah pada semester yang berangkutan atau ketepatan prioritas program yang dipilih.

1) Kelengkapan isi tiap jenis program yaitu :

2) Materi yang terinci

3) Pendekatan atau metode

4) Waktu

5) Audience

c. Pelaksanaan program bimbingan dan penyuluhan

1) Layanan pengumpulan data

2) Layanan konseling 
a. Proses penyuluhan

b. Pelaporan pelaksanaan penyuluhan

3) Layanan bantuan orientasi kesulitan belajar siswa

4) Laporan orientasi dan penyaajian informasi.

a. Orientasi kehudupan di sekolah.

b. Orientasi kehidupan disekolah sambungan.

c. Informasi tentang cara belajar.

d. Informasi tentang program pendidikan sekolah.

e. Informasi pekerjaan, jabatan atau karier

5) Layanan penempatan

6) Layanan rujukan atau alih tangan.

7) Menyusun alat-alat evaluasi yang aa atau menyusun bimbingan dan penyuluhan.

a. Memilih alat-alat evaluasi yang ada atau menyusun dan mengembangkan alatalat evaluasi.

b. Penggadaan alat-alat /instrumen evaluasi.

8) Pelaksanaan kegiatan evaluasi pelaksanaan BP.

a. Persiapan pelaksanaan kegiatan evaluasi.

b. Pelaksanaan kegiatan evaluasi.

c. Melaksanakan analisis hasil pelaksanaan bimbingan dan penyuluhan

9) Menganalis hasil pelaksanan BP.

a. Tabulasi data.

b. Analisi hasil pengumpulan data

10) Memanfaatkan hasil pelaksanaan BP.

a. Memilih alternatif yang paling tepat untuk tindak lanjut

b. Menyusun program tindak lanjut

c. Melaksanakan program tindak lanjut

11) Penilaian dan tindak lanjut

a. Penilaian hasil kegiatan BK dikelas dan tindak lanjut

b. Penilaian hasil kegiatan BK di ruang BP dan tindak lanjut

c. Penilaian hasil kegiatan BK di luar sekolah

d. Penilaian program BK secara keseluruhan. 


\section{KUMPULAN INSTRUMEN BK}

1. Tes Alat Ungkap Masalah (AUM)

2. Tes SSCT

3. Angket Sosiometri

4. Tes BDI (Becks Depression Inventory)

5. Tes PET (Personality Eysenck)

6. Tes Gaya Belajar

7. Tes Angket Berpikir Positif

8. Tes Kecerdasan Majemuk 


\section{$\underline{\text { Tes Alat Ungkap Masalah (AUM) }}$}

\section{Petunjuk :}

1. Dibawah ini ada bermacam - macam masalah, bila masalah ini sesuai dengan kondisi yang pernah di alami atau yang sedang anda alami, maka lingkarilah pada nomornya dilembar jawab yang tersedia.

2. Isilah dengan sejujur - jujurnya, tidak perlu khawatir.

Pengisian dengan sejujur - jujurnya akan sangat membantu kami dalam menganalisa masalah dan mencari solusi atau jalan keluar ynag tepat, sehingga sesuai dngan yang kita harapkan.

\section{KESEHATAN}

1. Badan terlalu kurus, atau terlalu gemuk

2. Warna kulit kurang memuaskan

3. Berat badan terus berkurang, atau bertambah.

4. Badan terlalu pendek, atau terlalu gemuk.

5. Secara jasmaniah kurang menarik.

6. Belum mampu memikirkan dan memilih pekerjaan yang akan dijabat nantinya.

7. Belum mengetahui bakat diri sendiri untuk jabatan/pekerjaan apa.

8. Kurang memiliki pengetahuan yang luas tentang lapangan pekerjaan dan seluk beluk jenisjenis pekerjaan.

9. Ingin memperoleh bantuan dalam mendapatkan pekerjaan sambilan untuk melatih diri bekerja sambil sekolah.

10. Khawatir akan pekerjaan yang dijabatnya nanti; jangan-jangan memberikan penghasilan yang tidak mencukupi.

11. Terpaksa atau ragu-ragu memasuki sekolah ini.

12. Meragukan kemanfaatan memasuki sekolah ini.

13. Sukar menyesuaikan diri dengan keadaan sekolah.

14. Kurang meminati pelajaran atau jurusan atau program yang diikuti.

15. Khawatir tidak dapat menamatkan sekolah pada waktu yang direncanakan.

16. Fungsi dan atau kondisi kesehatan mata kurang baik.

17. Mengalami gangguan tertentu karena cacat jasmani.

18. Fungsi dan atau kondisi kesehatan hidung kurang baik.

19. Kondisi kesehatan kulit sering terganggu.

20. Gangguan pada gigi

\section{KEADAAN PENGHIDUPAN}

21. Uang saku pemberian orang tua tidak mencukupi

22. Kekurangan buku karena malas membeli

23. Ayah pensiun dan tidak bekerja lagi

24. Ayah sudah mninggal dan ibu tidak bekerja

25. Ibu terpaksa harus bekerja karena ekonomi tidak mencukupi

26. Ibu bekerja sedangkan ayah tidak

27. Banyak adik yang menjadi tanggungan dalam keluarga

28. Tidak tahu harus bagaimana untuk menambah biaya sekolah 
29. Sering pinjam uang kepada teman atau orang lain

30. Tidak ada keinginan untuk melanjutkan sekolah

31. Ingin mempunyai kamar senidri

32. Penerangan lampu di rumah kurang mencukupi

33. Iuran sekolah sering terlambat dibayar

34. Sering mengendarai mobil sendiri ke sekolah

35. Iuran sekolah terlalu tinggi

36. Orang tua tidak punya penghasilan tetap

37. Tidak ada uang untuk membeli pakaian

38. Ayah dan ibu bercerai dan saya ikut ibu

39. Saya mengharapkan agar mendapat beasiswa

40. Tinggal atau ikut dengan saudara

\section{REKREASI dan HOBBY}

41. Hampir tidak mempunya1 waktu untuk bermain

42. Keinginan untuk rekreasi sering terhalang

43. Gemar melukis tetapi dilarang oleh orang tua

44. Waktu libur harus mngikuti les privat

45. Suka berolah raga tetapi tidak ada kesempatan

46. Tidak suka berolah raga

47. Hobby selalu mengganggu belajar

48. Lebih suka buku-buku hiburan daripada buku-buku sekolah

49. Saya senang nonton film di gedung film

50. Gemar melukis tetapi tidak mempunyai waktu

51. Tidak bisa memanfaatkan waktu senggang

52. Salah seorang anggota keluarga selalu menghalang-halangi hobby saya

53. Ingin belajar menari atau main sandiwara tetapi tidak diijinkan

54. Kesenangan membaca majalah atau komik sering menghabiskan waktu belajar

55. Habis waktu nonton tv

56. Karena sibuk orang tua tidak pernah mengajak rekreasi keluar kota

57. Hampir setiap minggu orang tua mengajak rekreasi keluar kota

58. Senang menyanyi tetapi tidak ada kesempatan

59. Kedatangan teman menghabiskan wsktu belajar saya

60. Waktu belajar habis untuk bermain.

\section{KEHIDUPAN SOSIAL dan KEAKTIFAN BERORGANISASI}

61. Tidak senang bermain dalam kelompok

62. Sering gagal dalam mencari teman

63. Merasa tidak disenangi kawan-kawan di luar sekolah

64. Suka bergaul

65. Tidak berminat dalam berorganisasi

66. Tidak terlalu aktif dalam berorganisasi

67. Sukar menyesuaikan diri

68. Merasa mudah tersinggung

69. Takut bergaul dengan kakak kelas

70. Tidak pernah jadi pemimpin

71. Tidak berani menemukakan suatu pndapat

72. Sukar menerima kekalahan

73. Sering bertentangan dengan orang lain 
74. Selalu ingin berkuasa dalam pergaulan

75. Bingung bial berhadapan ddengan orang banyak

76. Mudah merasa malu

77. Mudah untuk marah

78. Sering merasa tidak sabar

79. Sering tidak menepati janji

80. Sering ditegur karena kurang sopan

\section{HUBUNGAN PRIBADI}

81. Tidak suka bergaul dengan orang yang kedudukannya lebih rendah

82. Tidak suka bergaul dengan orang yang kedudukannya lebih tinggi

83. Sering merasa malu bergaul dengan teman jenis kelamin lain

84. Sering merasa iri hati

85. Sukar untuk mendapat teman

86. Tidak suka bertamu

87. Enggan menerima tamu atau teman ke rumah

88. Merasa tidak dihargai teman

89. Sering merasa curiga terhadap orang lain

90. Bersikap kaku dan tidak toleran

91. Bersifat dingin dalam pergaulan

92. Sering menyesali diri sendiri

93. Sering ingin bunuh diri

94. Merasa tidak mempunyai harapan (pesimis)

95. Ingin lebih menarik dan ingin sekali dikagumi

96. Tidak ingin punya sahabat

97. Tidak mempunyai kawan yang akrab

98. Merasa diri saya tidak sebaik orang lain

99. Mempunyai kebiasaan jelek (misalnya menggigit kuku dll )

100. Saya ingin hidup lebih tenang lagi

\section{PERGAULAN atau MUDA - MUDI}

101. Sering melamun memikirkan si dia

102. Tidak bisa belajar kalau belum menelepon si dia

103. Ragu-ragu terhadap pacar

104. Pacar sering mengajak saya jalan-jalan

105. Kesepian karena belum mendapat pacar

106. Iri melihat kawan berpasangan

107. Menggunakan banyak waktu untuk di mall atau diskotik

108. Memilih pacar sulit baginya

109. Mudah mencintai tetapi mudah melepaskan

110. Sering bertepuk sebelah tangan

111. Sering pulang larut malam

112. Sering diajak atau ditawari teman

113. Sering teman untuk berpacaran

114. Sukar bergaul dengan jenis kelamin lain atau lawan jenis

115. Dilarang berpacaran oleh orang tua

116. Lebih senang pergi sama teman daripada sama keluarga

117. Berpacaran melupakan kebutuhan yang penting sekali

118. Berteman dengan teman sejenis lebih menynangkan daripada teman lawan jenis 
119. Merasa lebih menyenangkan berteman dengan lawan jenis

120. Sering melanggar larangan orang tua atau backstreet dalam hal berpacaran

\section{VII.KEHIDUPAN KELUARGA}

\section{Saya anak tunggal}

122. Tidak hidup bersama kedua orang tua

123. Selalu bertangkar dengan adik ataupun kakak

124. Ayah dan Ibu pulang kerja terlalu malam

125. Tidak pernah bergembira dengan Ayah dan Ibu

126. Pertengkaran Ayah dan Ibu menggangu pikiran

127. Orang tua kurang memperhatikan saya

128. Orang tua terlalu banyak bepergian

129. Orang tua terlalu banyak menuntut

130. Sukar menyesuaikan diri dengan Ayah dan Ibu

131. Meras tidak betah tinggal di rumah

132. Kehidupan di rumah kurang teratur

133. Ingin mengadakan perubahan di rumah

134. Di keluarga kami kurang tolong-menolong

135. Ayah dan Ibu tidak hidup bersama

136. Keluarga kami berantakan

\section{MASA DEPAN dan CITA - CITA dan PENDIDIKAN atau PEKERJAAN}

137. Khawatir tidak bisa mandiri klak

138. Tidak terlalu akan berbuat apa setelah tamat

139. Sulit untuk menentukan cita-cita

140. Ingin melanjutkan ke perguruan tinggi yang terkenal

141. Ingin mengetahui bakat dan kemampuan yang dimiliki

142. Cita-cita tidak sesuai dengan kemampuan

143. Cita-cita tidak sesuai dengan prestasi belajar

144. Cita-cita tidak disetujui oleh orang tua

145. Cita-cita terganggu oleh hobby

146. Belum mempunyai cita-cita tertentu

147. Tidak ada orang yang membantu mengenali cita-cita saya

148. Cit-cita selalu gagal

149. Mudah terpengaruh oleh cita-cita orang lain

150. Masa depan tidak ditntukan olah usaha saat sekarang

151. Bingung untuk menetukan sekolah lanjutan setelah tamat SLTP nanti

\section{PENYESUAIAN TERHADAP KURIKULUM}

152. Pelayanan di sekolah terlalu berat

153. Pelayanan di sekolah terlalu ringan

154. Enggan mengikuti kegiatan-kegiatan di luar kelas

155. Sulit mengerti isi buku pelajaran

156. Saya merasa takut bila ada mata pelajaran yang akan ulangan

157. Tidak suka belajar

158. Tidak berminat terhadap buku-pelajaran

159. Nilai ulangan sering mendapat nialai rendah

160. Tidak senang belajar bersama

161. Sering mendapat kesukaran bila mendapat tugas PR 
162. Sukar menangkap dan mengikuti pelajaran fiiska dan matematika

163. Sukar mempelajari pelajaran Biologi

164. Merasa beban pelajaran terlalu berat

165. Merasa pelajaran tidak berguna

166. Sukar mnyesuaikan diri dngan suasana

\section{LAIN-LAIN}

167. Masalah apa yang menurut kamu belum tercantum diatas

168. Masalah-masalah apa yang menurut kamu paling menyulitkan

169. Sukakah kamu meluangkan waktu untuk membicarkan kesulitanmu ? Jika benar dengan siapa? 


\section{LEMBAR JAWABAN DAFTAR CEK MASALAH}

NAMA

JENIS KELAMIN

NO. INDUK

TGL. LAHIR

PETUNJUK PENGISIAN:

Lingkarilah nomor - nomor berikut yang tersedia didalam kolom sesuai dengan pilihan jawaban anda!

\begin{tabular}{|c|c|c|c|c|c|c|c|c|}
\hline $\begin{array}{c}\text { KESEH } \\
\text { ATAN } \\
(1)\end{array}$ & $\begin{array}{c}\text { K. } \\
\text { EKONOM } \\
\text { I } \\
(2)\end{array}$ & $\begin{array}{l}\text { REKR } \\
\text { EASI } \\
\& \\
\text { HOBY } \\
(3)\end{array}$ & $\begin{array}{c}\text { K. } \\
\text { SOSIA } \\
\text { L (4) }\end{array}$ & $\begin{array}{l}\text { PRIBADI } \\
\text { (5) }\end{array}$ & $\begin{array}{c}\text { PERGA } \\
\text { ULAN } \\
(6)\end{array}$ & $\begin{array}{l}\text { KELUAR } \\
\text { GA (7) }\end{array}$ & $\begin{array}{c}\text { DEPAN } \\
\text { \& CITA } \\
\text { - CITA } \\
(8)\end{array}$ & $\begin{array}{c}\text { PENYES } \\
\text { UAIAN } \\
\text { BELAJAR } \\
\text { (9) }\end{array}$ \\
\hline 1 & 21 & 41 & 61 & 81 & 101 & 121 & 137 & 152 \\
\hline 11 & 31 & 51 & 71 & 91 & 111 & 131 & 147 & 162 \\
\hline 2 & 22 & 42 & 62 & 82 & 102 & 122 & 138 & 153 \\
\hline 12 & 32 & 52 & 72 & 92 & 112 & 132 & 148 & 163 \\
\hline 3 & 23 & 43 & 63 & 83 & 103 & 123 & 139 & 154 \\
\hline 13 & 33 & 53 & 73 & 93 & 113 & 133 & 149 & 164 \\
\hline 4 & 24 & 44 & 64 & 84 & 104 & 124 & 140 & 155 \\
\hline 14 & 34 & 54 & 74 & 94 & 114 & 134 & 150 & 165 \\
\hline 5 & 25 & 45 & 65 & 85 & 105 & 125 & 141 & 156 \\
\hline 15 & 35 & 55 & 75 & 95 & 115 & 135 & 151 & 166 \\
\hline 6 & 26 & 46 & 66 & 86 & 106 & 126 & 142 & 157 \\
\hline 16 & 36 & 56 & 76 & 96 & 116 & 136 & 143 & 158 \\
\hline 7 & 27 & 47 & 67 & 87 & 107 & 127 & 144 & 159 \\
\hline 17 & 37 & 57 & 77 & 97 & 117 & 128 & 145 & 160 \\
\hline 8 & 28 & 48 & 68 & 88 & 108 & 129 & 146 & 161 \\
\hline 18 & 38 & 58 & 78 & 98 & 118 & 130 & & \\
\hline 9 & 29 & 49 & 69 & 89 & 109 & & & \\
\hline 19 & 39 & 59 & 79 & 99 & 119 & & & \\
\hline 10 & 30 & 50 & 70 & 90 & 110 & & & \\
\hline 20 & 40 & 60 & 80 & 100 & 120 & & & \\
\hline
\end{tabular}

setelah menjawab masing - masing kolom maka jumlahkanlah dimasing - masing kolomnya
NAMA SEKOLAH :

KELAS

TGL. SEKARANG : 


\section{TES SSCT}

Nama

Tanggal

Petunjuk

Di bawah ini ada 60 butir kalimat yang belum lengkap. Bacalah masing - masing dan selesaikanlah dengan mengisikan apa yang pertama-tama muncul dalam dirimu. Bekerjalah secepat-cepatnya, bila ada yang dapat kamu kerjakan lingkarilah nomornya dan kembalilah mengerjakannya kemudian.

1. Saya rasa ayahku jarang.

2. Meskipun nasib sedang menimpa diriku.....

3. Saya selalu ingin untuk

4. Bila saya bertugas

5. Bagiku masa depan nampak

6. Guru-guru saya

7. Saya tahu kalau aneh saya tidak berani

8. Saya rasa teman yang sejati

9. Sewaktu saya kecil

10. Gagasanku yang sempurna

11. Bila kulihat seorang laki-laki dan wanita bersama-sama

12. Dibandingkan dengan banyak keluarga, keluargaku

13. Dalam pekerjaan, saya baik sekali dengan

14. Ibuku

15. Saya akan melakukan apapun untuk melupakan

16. Andaikata saya ayahku

17. Saya percaya bahwa saya mampu untuk

18. Saya akan berbahagia benar bila

19. Bila orang bekerja untukku

20. Saya berharap untuk

21. Disekolah guru-guruku

22. Kebanyakan teman-temanku tidak tahu bahwa saya takut terhadap

23. Saya tidak menyukai orang

24. Sebelum masuk sekolah saya

25. Saya kira kebanyakan gadis-gadis

26. Perasaanku mengenal kehidupan berteman dengan lain jenis

27. Keluargaku memperlakukan saya

28. Mereka yang bekerja denganku

29. Ibuku dan saya

30. Kesalahanku yang terbesar adalah

31. Saya berharap ayahku

32. Kelemahanku yang terbesar adalah

33. Rahasia cita hidupku

34. Orang-orang yang bekerja untukku

35. Suatu hari saya...

36. Bila saya melihat kepala sekolah datang

37. Saya ingin mehilangkan takut kepada.

38. Orang yang paling saya sukai 
39. Andaikata saya kembali muda

40. Saya percaya kebanyakan wanita

41. Bila saya berpacaran

42. Kebanyakan keluarga yang saya kenal adalah

43. Saya senang bekerja dengan orang yang

44. Saya kira kebanyakan ibu-ibu

45. Sewaktu saya muda

46. Saya merasa bahwa ayahku adalah

47. Bila nasib baik menghindariku

48. Dalam memberikan perintah kepada orang lain

49. Apa yang saya inginkan sekali dari kehidupan

50. Bila saya lebih tua 51. Orang-orang yang saya pandang di atasku

52. Ketakutanku kadang-kadang memaksaku untuk

53. Bila saya sedang tidak ada, teman-temanku

54. Kenangan masa kanak-kanakku yang paling jelas

55. Yang paling sedikit yang kusukai tentang wanita

56. Kehidupan seksku

57. Sewaktu kanak-kanak, keluargaku

58. Orang-orang yang bekerja dengan saya biasanya

59. Saya suka pada ibuku tetapi

60. Yang paling jelek pernah saya lakukan 


\section{ANGKET SOSIOMETRI}

Nama : ..................................................................L / P :

Umur : .............................................................. Alamat :

Isilah titik titik dibawah ini dengan sejujurnya:

1. Pilihlah 3 (tiga) orang teman anda dalam kelas ini yang anda senangi untuk diajak belajar bersama:

b......................................................., alasannya

C......................................................., alasannya

2. Pilihlah seorang teman anda yang paling anda senangi untuk menjadi ketua kelompok belajar:

alasannya.

3. Pilihlah teman anda yang paling anda senangi untuk menjadi ketua kelas:

, alasannya

4. Pilihlah 3 (tiga) orang teman anda dalam kelas ini yang anda senangi untuk diajak bermain-main bersama (misalnya: kesenian, olahraga, dan lain-lain):

, alasannya

b.........................................................., alasannya

C........................................................., alasannya.

5. Pilihlah 3 (tiga) orang teman anda dalam kelas ini yang kurang anda senangi:

a........................................................, alasannya

b.................................................., alasannya

C...................................................., alasannya

6. Pilihlah seorang teman anda dalam kelas ini yang paling tidak anda senangi:

alasannya 


\section{Tes BDI (Becks Depression Inventory)}

\section{Petunjuk:}

Pada saat anda mengisi kuesioner ini, bacalah setiap soal seksama dan lingkarilah nomor pada lembar jawaban yang paling mencerminkan apa yang anda rasakan selama beberapa hari ini. Pastikan bahwa anda menjawab semua pertanyaan ini. Jika lebih dari satu jawaban yang cocok untuk anda, maka lingkarilah nomor yang paling tinggi. Jika raguragu tentukanlah mana yang anda rasa paling baik. Jangan sampai ada pertanyaan yang tidak terjawab.

0 . Saya tidak merasa sedih

1. Saya merasa sedih

2. sepanjang waktu saya sedih dan tidak bisa menghilangkan perasaan itu

3. Saya sedemikian sedih dan tidak bahagia sehingga saya tidak tahan lagi rasanya

0. Saya tidak terlalu berkecil hati mengenai masa depan saya

1. Saya merasa kecil hati tentang masa depan

2. Saya merasa tidak ada suatupun yang saya harapkan

3. Saya merasa bahwa masa depan saya tanpa harapan dan bahkan semuanya tidak akan membaik

0. Saya tidak menganggap diri saya sebagai seorang yang gagal

1. Saya merasa bahwa saya telah gagal lebih dari kebanyakan orang

2. Saat saya menengok masa lalu, maka yang terlihat oleh saya hanya kegagalan

3. Saya merasa bahwa saya adalah seorang yang gagal total

0. Saya memperoleh banyak kepuasan dari hal-hal yang saya lakukan, sama seperti sebelumnya

1. Saya tidak lagi menikmati berbagai hal, seperti yang pernah saya rasakan dulu

2. Saya tidak memperoleh kepuasan sejati dari apapun lagi

3. Saya tidak puas dan bosan dengan segalanya

0. Saya tidak terlalu merasa bersalah

1. Saya merasa bersalah di hampir tiap waktu

2. Saya merasa bersalah di hampir sebagian waktu saya

3. Saya merasa bersalah di sepanjang waktu

0. Saya tidak merasa seolah saya sedang dihukum

1. Saya merasa mungkin saya sedang dihukum

2. Saya pikir saya akan dihukum

3. Saya merasa bahwa saya sedang dihukum

0. Saya tidak merasa kecewa terhadap diri saya sendiri

1. Saya agak kecewa terhadap diri saya sendiri

2. Saya kecewa terhadap diri saya sendiri

3. Saya membenci diri saya sendiri 
0. Saya tidak merasa lebih buruk daripada orang lain

1. Saya cela diri saya sendiri karena kelemahan atau kesalahan saya

2. Saya menyalahkan diri saya sepanjang waktu karena kesalahan-kesalahan saya

3. Saya menyalahakan diri saya untuk semua hal buruk yang terjadi

0. Saya tidak punya pikiran sedikitpun untuk bunuh diri

1. Saya ingin bunuh diri

2. Saya kecewa terhadap diri saya sendiri

3. Saya akan bunuh diri jika ada kesempatan

0. Saya tidak lebih banyak menangis dibandingkan biasanya

1. Sekarang saya lebih banyak menangis daripada sebelumnya

2. Saya sekarang menangis sepanjang waktu

3. Biasanya saya mampu menangis, namunkini saya tidak lagi bisa menangis walaupun saya menginginkannya

0. Saya tidak terganggu oleh berbagai hal dibandingkan biasanya

1. kini saya sedikit lebih parah dibandingkan biasanya

2. Saya agak jengkel dan terganggu di sebagian besar waktu saya

3. Kini saya merasa jengkel sepanjang waktu

0. Saya tidak kehilangan minat terhadap orang lain

1. Saya agak kurang berminat terhadap orang lain dibandingkan biasanya

2. Saya kehilangan hamper seluruh minat saya terhadap orang lain

3. Saya telah kehilangan minat saya pada orang lain

0. Saya mengambil keputusan hamper sama baiknya dengan yang biasanya saya lakukan

1. Saya menunda mengambil keputusan lebih sering dari yang biasanya saya lakukan

2. Saya mengalami kesulitan besar dalam mengambil keputusan daripada sebelumnya

3. Saya sama sekali tidak dapat mengambil keputusan lagi

0. Saya tidak merasa bahwa keadaan saya tampak lebih buruk dari yang biasanya

1. Saya kuatir tampak tua dan tidak menarik

2. Saya merasa ada perubahan yang permanent dalam penampilan saya sehingga membuat saya nampak tidak menarik

3. Saya yakin bahwa saya nampak jelek

0. Saya dapat bekerja sama baiknya dengan waktu-waktu sebelumnya

1. Saya membutuhkan suatu usaha ekstra untuk memulai melakukan sesuatu

2. Saya harus memaksa diri sekuat tenaga untuk melakukan sesuatu

3. Saya tidak mampu melakuakan apapun lagi

0. Saya dapat tidur seperti biasanya

1. Tidur saya tidak nyenyak seperti biasanya

2. Saya bagun 1-2 jam lebih awal dari biasanya dan merasa sukar sekali untuk bisa tidur kembali

3. Saya bangun beberapa jam lebih awal daripada biasanya serta tidak dapat tidur kembali

0. Saya tidak merasa lebih lelah dari biasanya

1. Saya merasa lebih mudah lelah dari biasanya 
2. Saya merasa lelah setelah melakukan apa saja

3. Saya terlalu lelah untuk melakukan apapun

0. Nafsu makan saya tidak lebih buruk dari biasanya

1. Nafsu makan saya tidak sebaik biasanya

2. Nafsu makan saya kini jauh lebih buruk

3. Saya tidak memiliki nafsu makan lagi

0. Berat badan saya tidak turun banyak, atau bahkan tetap akhir-akhir ini

1. Berat badan saya turun lebih dari 5 kilogram

2. Berat badan saya turun lebih dari 10kilogram

3. Berat badan saya turun lebih dari 15 kilogram

0. Saya tidak cemas mengenai kesehatan saya dari biasanya

1. Saya cemas mengenai masalah fisik seperti masalah sakit dan tidak enak badan atau perut mual dan sembelit

2. Saya cemas mengenai masalah fisik dan sukar memikirkan banyak hal lainnya

3. Saya cemas mengenai masalah fisik saya sehingga tidak dapat berpikir tentang hal yang lainnya

0. Saya tidak melihat adanya perubahan dalam minat saya terhadap lawan jenis

1. Saya kurang berminat terhadap lawan jenis dibandingkan biasanya

2. Kini saya sangat kurang berminat terhadap lawan jenis

3. Saya telah kehilangan minat terhadap lawan jenis sama sekali 


\section{TES PET (PERSONALITY EYSENCK)}

1. Apakah Saudara merasa sanggup melakukan banyak hal sama baiknya seperti kenanyakan orang?

2. Apakah saudara merasa memperoleh lebih banyak kesialan dari pada yang saudara perkirakan?

3. Apakah saudara lebih sering marah dibandingkan kebanyakan orang ?

4. Apakah saudara kadang - kadang mempunyai ode yang selalu saudara pikirkan, sedangka saudara ingin menghentikannya tetapi tidak dapat .

5. Adakah sesuatu tabiat ( seperti merokok ) yang ingin saudara hentikan tetapi tidak dapat ?

6. Apakah saudara selalu sehat dan kuat ?

7. Apakah saudara sering merasa terganggu oleh perasaan - perasaan bersalah ?

8. Apakah saudara merasa hanya mempunyai sedikit yang dapat saudara banggakan ?

9. Apakah saudara merasa lesuh ketika saudara bangun pagi ?

10. Apakah saudara sering kurang tidur akibat kekhawatiran saudara?

11. Apakah saudara inginmenghitung - hitung waktu ( jam, hari dst )?

12. Jika saudara melihat suatu pekerjaan dan saudara ingin melakukannya, apakah biasanya saudara mencoba melakukannya?

13. Apakah saudara sering tidak mempunayi nafsu makan?

14. Apakah saudara sering meminta maaf walaupun saudara sebenarnya tidak bersalah ?

15. Apakah saudara sering menganggap diri saudara sebagai orang yang gagal ?

16. Apakah suadara merasa puas dengan kehidupan saudara sekarang ?

17. Apakah saudara selalu dalam keadaan tenang dan tidak binging ?

18. Apakah saudara membaca suatu kalimat yang mengandung suatu kesalahan dalam ejaan atau tanda baca, saudara merasa sulit untuk memahaminya ?

19. Apakah saudara mengontrol badan dengann melakukan latihan atau diet ?

20. Apakah kulit saudara sangan sensitive dan lembut?

21. Apakah saudara kadang- kadang merasa mengecewakan orang tua dengan kehidupan yang saudara tempuh?

22. Apakah saudara menderita perasaan rendah diri ?

23. Apakah saudara menemukan banyak kesenangan dalam hidup ?

24. Apakah kadang saudara mempunyai terlalu banyak kesulitan sehingga saudara tidak dapat mengatasinya?

25. Apakah saudara kadang terdorong untuk mencuci tangan meskipun saudara itu tahu bahwa tangan saudara itu bersih?

26. Apakah saudara merasa bahwa kepribadian saudara dibentuk oleh hal - hal yang terjadi sejak masa kanak - kanaj, sehingga tidak banyak saudara perbuat untuk merubahnya?

27. Apakah saudara sering merasa pusing ?

28. Apakah saudara merasa telah melakukan dosa - dosa yang tidak dapat diampuni ?

29. Umumnya apakah saudara yakin kepada diri saudara sendiri ?

30. Apakah kadang - kadang saudara merasa tidak menghiraukan apa yang terjadi pada diri saudara?

31. Apakah kehidupan sering merupakan beban bagi saudara ?

32. Apakah saudara kadang - kadang tergangu oleh pikiran yang selalu ada selama berhari hari ?

33. Apakah saudara membuat keputusan sendiri tanpa menghiraukan yang dikatakan orang lain ?

34. Apakah saudara sering menderita sakit kepala yang lebih sering daripada orang lain ?

35. Apakah saudara sering merasakan adanya dorongan yang kuat untuk mengakui sesuatu yang telah saudara perbuat? 
36. Apakah saudara sering menginginkan seandainya saudara menjadi oranglain ?

37. Apakah saudara sekarang berada dalam kondisi jiwa yang sehat?

38. Ketika saudara masik kecil apakah saudara takut akan tempat yang gelap ?

39. Apakah saudara terdorong untuk menurutkan kata hati dalam hal - hal kecil yang bersifat tahayyul seperti tidak menyapu di malan hari ?

40. Apakah saudara merasa sulit untuk mengontro beban berat badan ?

41. Apakah saudara kadang - kadang berkedut pada muka, kepala, bahu dsb ?

42. Apakah saudara sering merasa orang lain mencela tingkah laku saudara ?

43. Apakah saudara sering merasa terganggu oleh perasaan - perasaan tidak mampu jika saudara harus membuat suatu pidato ?

44. Apakah saudara pernah merasa pendendam tanpa ada alas an?

45. Apakah saudara sering merasa tidak jelas seperti menginginkan sesuatu tetapi tidak tahu apa yang diinginkan?

46. Apakah saudara sering terdorong untuk selalu mengunci candela, pintu, tas dll ?

47. Apakah saudara menyerahkan pada tuhan atau takdir untuk menbaga keselamatan saudara ?

48. Apakah saudara sangat khawatir untuk menderita suatu penyakit?

49. Apakah saudara yakin bahwa kesenangan yang diperoleh sekarang pada akhirnya harus saudara bayar kembali ?

50. Apakah terdapat banyak hal yang ingin saudara rubah sekiranya dapat dirubah ?

51. Apakah saudara memandang masa depan sebagai sesuatu yang kelihatan cerah ?

52. Apakah saudara biasanya berkeringat dan gemetar bila dihadapkan pada tugas yang sulit?

53. Apakah saudara secara rutin memeriksa seluruh penerangan, alat - alat rumah tangga, sebelum saudara pergi tidur?

54. Apakah ada sesuatu yang salah, apakah saudara biasanya mengatakan sebagai nasib yang sial daripada pengelolaan yang buruk?

55. Apakah saudara pergi ke dokter walaupun demam sedikit saja ?

56. Apakah saugara sangat mementingkan untuk hidup lebih baik daripada kebanyakan orang ?

57. Apakah saudara merasa cukup dikenal dengan banyak orang ?

58. Pernahkah saudara berkeinginan untuk mati ?

59. Apakah saudara sering merasa takut pada sesuatu benda atau orang yang sebenarnya saudara tahu tidak akan mencelakakan saudara?

60. Apakah saudara sering menyediakan makanan kering didalam rumah untuk menjada - jaga kekurangan makanan?

61. Apakah saudara pernah merasa seakan-akan dirasuki roh jahat?

62. Apakah saudara banyak mengalami keletihan akibat kegugupan?

63. Apakah sesuatu yang telah anda perbuat yang akan anda sesali seumur hidup?

64. Apakah saudara sangat yakin akan keberhasilan putusan - putusan saudara ?

65. Apakah saudara sering merasa sedih ?

66. Apakah saudara sering merasa cemas daripada orang lain ?

67. Apakah kotoran sangay menjijikkan saudara?

68. Apakah saudara sering merasa sebagi korban kekuasaan luar yang tidak dapat anda kendalikan?

69. Apakah anda sering merasa sakit - sakitan ?

70. Apakah saudara sering merasa disalahkan atau dihukum ?

71. Apakah saudara menganggap diri saudara terlalu tinggi?

72. Apakah berbagai hal kelihatan terlalu sia - sia bagi anda ?

73. Apakah saudara sering mencemaskan berbagai hal yang sebenarnya tidak perlu saudara cemaskan?

74. Jika saudara tinggal; di suatu tempat yang bukan rumah anda apakah anda membuat rencana tentang bagaimana caranya melepaskan diri bila terjadi kebakaran ? 
75. Apakah saudara merencanakan suatu tindakan untuk mendapatkan apa yang saudara inginkan daripada berserah diri pada nasib ?

76. Apakah saudara menyediakan bermacam - macam obat dirumah anda ?

77. Apakah saudara suka menyimpan dalam hati jika ada orang yang mencaci anda ?

78. Apakah saudara sering merasa malu terhadap hal - hal yang pernah anda lakukan ?

79. Apakah saudara gembira seperti kebanyakan orang ?

80. Apakah saudara sering mencemaskan sesuatu atau seseorang ?

81. Apakah saudara mudah jengkel terhadap hal - hal yang tidak pada tempatnya ?

82. Pernahkah saudara membuat keputusan dengan cara undian ?

83. Apakah saudara terlalu mencemaskan masalah kesehatan anda ?

84. Jika saudara mendapatkan kecelakaan apakah saudara menganggapnya sebagai hokum karma?

85. Apakah saudara merasa malu apabila melihat foto saudara karena tidak sesuai dengan selera anda?

86. Apakah saudara sering merasa tidak bergairah dan letih tanpa suatu sebab ?

87. Jika saudara membuat kesalahan meskipun kecil apakah saudara sulit melupakannya ?

88. Apakah saudara memperhitungkan secara teliti seluruh pengeluaran anda ?

89. Apakah saudara sering bertindak berlawanan dengan keinginan - keinginan orang tua saudara?

90. Apakah saudara merasa sakit tidak dapat berkonsentrasi pada pekerjaan saudara?

91. Apakah saudara menyesali pengalaman - pengalaman yang terlalu awal ?

92. Adakah anggota keluarga saudara yang membuat saudara merasa kurang enak ?

93. Apakah saudara sering terganggu oleh suara bising ?

94. Apakah saudara dengan mudah merasa rilek dengan duduk atau berbaring ?

95. Apakah saudara merasa khawatir tertular penyakit dari orang lain ?

96. Apakah saudara merasa kesepian dan berusaha bersikap rama terhadap orang lain ?

97. Apakah saudara merasa terganggu oleh rasa gatal yang hebat ?

98. Apakah saudara mempunyai beberapa sifat buruk yang tidak bisa diperbaiki ?

99. Apakah saudara sangat terganggu juka jika seseorang mengkritik saudara ?

100. Apakah saudara merasa sering dipermalukan dengan curang dalam hidup ini ?

101. Apakah saudara mudah kaget dengan hadirnya seseorang yang tidak diduga ?

102. Apakah saudara selalu berhati - hati membayar kembali hutang saudara meskipun hanya beberapa rupiah?

103. Apakah saudara sering merasa sulit untuk mengendalikan hawa nafsu saudara?

104. Apakah saudara merasa sehat?

105. Apakah saudara merasa terganggu oleh kepedihan suara hati ?

106. Apakah iorang menghargai saudara sebagai orang yang berguna Jika saudara berada ditengah - tengah mereka?

107. Apakah saudara merasa bahwa orang lain tidak mempedulikan apa yang terjadi pada diri saugara?

108. Apakah saudara merasa sulit untuk duduk dengan tenang ?

109. Apakah saudara sering melakukan sendiri berbagai pekerjaan daripada mempercayakan pada orang lain?

110. Apakah saudara terbujuk oleh uraian - uraian atau alas an - alas an orang lain ?

111. Apakah sakit perut sering terjadi pada keluarga anda ?

112. Apakah saudara menganggap masa mudah tidak anda gunakan dengan sebaik - baiknya ?

113. Apakah anda sering mempertanyakan keberadaan saudara sebagai seorang manusia ?

114. Apakah saudara sering merasa kesepian?

115. Apakah saudara sangat khawatir mengenai uang ?

116. Apakah saudara lebih suka menyeberang jalan daripada harus naik jembatan penyebrangan?

117. Apakah saudara sering merasa bahwa kehidupan ini sangat sulit ditanggulangi ? 
118. Apakah orang lain tidak menaruh simpati ketika saudara merasa tidak sehat ?

119. Ap[akah saudara merasa tak pantas menerima kepercayaan dan kasih saying dari orang lain?

120. Apabila orang - orang mengatakan hal - hal yang baik tentang diri saudara apakah saudara merasa sukar untuk mempercayainya?

121. Apakah saudara merasa mempunyai sesuatu yang dapat disumbangkan kepada bangsa dan Negara?

122. Apakah saudara dapat tidur dengan mudah di waktu malam hari ?

123. Dapatkah saudara dengan mudamelupakan kesalahan - kesalahan yang kecil ?

124. Apakah hal - hal yang saudara lakukan p[ada umumnya sesuai dengan keinginan orang lain?

125. Apakah saudara sering sekali menderita sembelit ( sukar buang air besar )

126. Apakah sering mengingat kembali hal - hal yang terjadi di masa lalu, dan rasanya saudara ingin bersikap lebih bertanggung jawab ?

127. Apakah saudara tidak menyatakan pendapat - pendapat saudara karena takut dikritik orang lain?

128. Adakah sekurang - kurangnya satu orang didunia ini yang benar - benar mencintai saudara ?

129. Apakah saudara mudah merasa kikuk dalam suatu pertemuan atau pesta ?

130. Apakah saudara mengumpulkan berbagai jemis bahan yang tidak berguna, dengan pemikiran siapa tahu suatu saat nanti dibutuhkan?

131. Apakah saudara percaya bahwa masa depak berada di tangan saudara sendiri ?

132. Apakah saudara pernah mengalami ketegangan syataf?

133. Apakah saudara menyimpan rahasia bersalah yang saudara khawatir pada suatu hari akan terbuka?

134. Apaka saudara merasa ,malu atau rendah diri dalam pertemuan - pertemuan ?

135. Apakah saudara sependapat bahwa tidak sepantasnya membawa anak kedalam kehidupan yang keadaannya seperti sekarang ?

136. Apakah saudara mudah merasa gemas apabila hal - hal yang direncanakan tidak berjalan sebagaimana mestinya?

137. Apakah saudara merasa risau jika rumah saudara tidak tertata rapih ?

138. Apakah saudara memiliki kemampuan yang sama kuatnya dengan orang yang dekat dengan saudara?

139. Apakah saudara sering terganggu oleh detakan jantung saudara?

140. Apakah saudara yakin bahwa kelakuan yang buruk akan selalu mendapatkan hukuman pada suatu saat nanti ?

141. Apakah saudara mempunyai kecenderungan merasa dibawa orang saudara temui walaupun secara obyektif tidak lebih dari saudara?

142. Secara umum apakah tujuan yang saudara capai dalam hidup ini telah tyercapai ?

143. Apakah saudara sering terbangun dan berkeringat karena mengalami mimpi buruk ?

144. Apakah saudara jijik jika binatang piaraan seseorang menjilat kaki saudara?

145. Hanya membuang - buang waktu saja merencanakan lebih dahulu kegiatan yang akan dilakukan karena sesuatu akan selalu terjadi yang mengakibatkan berubahnya rencana rencana anda, benarkah itu menurut saudara?

146. Apakah saudara mengkhawatirkan salah satu anggota saudara anda sakit?

147. Jika saudara telah berbuat sesuatu yang secara moral patut dicela apakah saudara mudah melupakannya?

148. Apakah biasanya saudara dapat mengerjakan hal- hal yang saudara inginkan ?

149. Apakah saudara sering dilanda kesepian ?

150. Apakah suara saudara bergetar jika saudara sedang berbicara kepada seseorang yang ingin saudara kecam?

151. Apakah saudara terus melakukan sesuatu tanpa minta pertolongan yang sebenarnya sangat saudara butuhkan daripada merasa berhutang budi kepada orang lain ? 
152. Apakah saugara lebihmengutamakan pekerjaan dimana orang lain memutuskan apa yang harus saudara lakukan?

153. Apakah saudara terganggu oleh rasa dingin pada tangan ,kaki saudara walaupun pada cuaca yang hangat?

154. Apakah saudara sering berdoa untuk mohon pengampunan?

155. Apakah saudara puas dengan penampilan saudara?

156. Apakah saudara merasa bahwa orang lainlah yang selalu bernasib baik?

157. Apakah saudara tetap tenang dalam keadaan gawat?

158. Apakah saudara menganggap penting untuk mencatat seluruh janji atau jadwal pertemuan bahkan yang akan saudara lakukan pada hari itu ?

159. Apakah saudara sering mempunyai perasaan bahwa tidak ada gunanya pergi ketempat lain ( mencoba transmigrasi ) ?

160. Apakah saudara sering sukar bernafas ?

161. Apakah saudara malu mengengan cerita - cerita porno ?

162. Apakah saudara sering diam terhadap orang lain karena saudara piker mereka tidak menyukai anda?

163. Apakah sudah lama berlalu saat saudara sedang berada di puncak keberhasilan?

164. Apakah saudara kadang - kadang mengalami ketegangan ?

165. Apakah saudara biasanya memperbaiki rambut dan baju sebelum saudara membukakan pintu bagi seorang tamu?

166. Apakah saudara sering tidak mampu mengendalikan diri anda?

167. Apakah saudara merasa hanya membuang - buang waktu pergi ke dokter untuk penyakit yang eingan seperti batuk, pilek demam dll ?

168. Apakah saudara sering merasa seakan - akan telah berbuat salah meskipun perasaan itu tidak beralasan?

169. Apakah saudara merasa sukar untuk menarik perhatian?

170. Apakah saudara merasa tertipu atau diperlakukan dengan curang oleh orang lain ?

171. Apakah saudara mencemaskan pengalaman - pengalan dalam waktu yang sangat lama ?

172. Apakah saudara sering tergoda untuk memperbaiki ?

173. Tata bahasa orang ketika saudara sedang berbicara dengan mereka?

Apakah saudara merasa bahwa segalanya berubah dengan sangat cepatnya sehingga sulit untukmengetahui kaidah - kaidah mana yang harus diikuti ?

174. Apakah saudara langsung ketempat tidur jika saudara mendapat serangan demam ?

175. Apakah saudara mengira bahwa saudara pasti telah mengecewakan guru - guru saudara di sekolah karena saudara tidak belajar cukup rajin ?

176. Apakah saudara saling berpura - pura sebagai orang yang lebih baik dari keadaan saudara yang sebenarnya ?

177. Apakah saudara kira - kira samka gembiranya dengan orang sebelah ?

178. Apakah saudara merasa bahwa saudara adalah orang yang tahu diri ?

179. Apakah saudara melukiskan diri saudara sebagai seorang yang ingin segalanya sempurna ?

180. Apakah saudara mempunyai sasaran - sasaran yang jelas yang harus saudara tuju dalam hidup saudara?

181. Apakah saudara sering melihat warna lidah saudara di pagi hari ?

182. Apakah saudara sering mengingat betapa buruknya perlakuan saudara terhadap orang lain dimasa lalu?

183. Apakah saudara kadang - kadang merasa bahwa saudara tak sanggup berbuat apaun dengan benar?

184. Apakah saudara sering mempunyai perasaan bahwa saudara bukanlah bagian dari sesuatu $?$

185. Apakah saudara mencemaskan hal - hal yang mungkin akan terjadi ?

186. Apakah saudara melakukan sesuatu kebiasaan tertentu menjelang tidur yang jika terputus menyebabkan saudara sukar tidur?

187. Apakah saudara sering merasa bahwa orang lain sedang menggunakan saudara?

188. Apakah saudara menimbang badan saudara setiap hari ? 
189. Apakah saudara yakin Tuhan akan menghukum dosa - dosa saudara pada akhir jaman?

190. Apakah saudara sering meragukan kegagahan seksual saudara?

191. Apakah tidur saudara biasanya gelisah dan terganggu ?

192. Apakah saudara cenderung memikirkan hal - hal yang tidak berguna secara berulang ulang?

193. Apakah sangat penting bagi saudara agar segala sesuatu selalu rapih ?

194. Apakah saudara kadang - kadang terpengaruh oleh iklan - iklan untuk membeli sesuatu yang tidak begitu saudara inginkan sebelumnya ?

195. Apakah saudara sering terganggu oleh suara - suara mendenging dalam telinga saudara ?

196. Apakah saudara biasanya menyerahkan diri saudara jika terjadi suatu kesalahan dalam hubungan pribadi saudara?

197. Apakah saugara merasa bahwa saudara berkemampuan sama dengan kebanyakan orang ?

198. Apakah saudara sering merasa kesepian meskipun ketika saudara berada ditengah - tengah orang banyak?

199. Apakah saudarapernah merasa membutuhkan obat penenang ?

200. Apakah saudara sangat bingung jika kebiasaan sehari - hari saudara terganggu oleh peristiwa - peristiwa yang tidak diduga sebelumnya ?

201. Apakah saudara membaca perbintangan untuk mendapatkan sebamam tuntunan dalam hidup?

202. Apakah sudara sering merasa kerongkongan saudara seperti tersumbat ketika ingin mengatakan sesuatu?

203. Apakah kadang-kadang saudara merasa jijik terhadap keinginan-keinginan seksual anda?

204. Apakah saudara merasakan ketenangan dan kepuasan dalam hidup?

205. Apakah saudara seorang yang sering gugup?

206. Apakah saudara yakin bahwa kepribadian saudara menarik bagi lawan jenis saudara?

207. Apakah saudara menyimpan dan menyususn surat-surat saudara, sehingga saudara akan dapat mengetahui dengan tepat segala sesuatunya jika saudara membutuhkannya?

208. Apakah biasanya orang lain yang memutuskan sesuatu yang akan saudara saksikan?

209. Apakah saudara mempunyai masa-masa saudara merasa panas atau kedinginan?

210. Apakah saudara mudah melupakan hal-hal yang salah yang telah saudara perbuat? 
LEMBAR JAWABAN

Personality Eysenck

\begin{tabular}{|c|c|c|c|c|c|c|c|}
\hline Nilai & Nilai & Nilai & Nilai & Nilai & Nilai & \multicolumn{2}{|c|}{ Nilai } \\
\hline 1 & 2 & 3 & 4 & 5 & 6 & 7 & \\
\hline 8 & 9 & 10 & 11 & 12 & 13 & 14 & \\
\hline 15 & 16 & 17 & 18 & 19 & 20 & 21 & \\
\hline 22 & 23 & 24 & 25 & 26 & 27 & 28 & \\
\hline 29 & 30 & 31 & 32 & 33 & 34 & 35 & \\
\hline 36 & 37 & 38 & 39 & 40 & 41 & 42 & \\
\hline 43 & 44 & 45 & 46 & 47 & 48 & 49 & \\
\hline 50 & 51 & 52 & 53 & 54 & 55 & 56 & \\
\hline 57 & 58 & 59 & 60 & 61 & 62 & 63 & \\
\hline 64 & 65 & 66 & 67 & 68 & 69 & 70 & \\
\hline 71 & 72 & 73 & 74 & 75 & 76 & 77 & \\
\hline 78 & 79 & 80 & 81 & 82 & 83 & 84 & \\
\hline 85 & 86 & 87 & 88 & 89 & 90 & 91 & \\
\hline 92 & 93 & 94 & 95 & 96 & 97 & 98 & \\
\hline 99 & 100 & 101 & 102 & 103 & 104 & 105 & \\
\hline 106 & 107 & 108 & 109 & 110 & 111 & 112 & \\
\hline 113 & 114 & 115 & 116 & 117 & 118 & 119 & \\
\hline 120 & 121 & 122 & 123 & 124 & 125 & 126 & \\
\hline 127 & 128 & 129 & 130 & 131 & 132 & 133 & \\
\hline 134 & 135 & 136 & 137 & 138 & 139 & 140 & \\
\hline 141 & 142 & 143 & 144 & 145 & 146 & 147 & \\
\hline 148 & 149 & 150 & 151 & 152 & 153 & 154 & \\
\hline 155 & 156 & 157 & 158 & 159 & 160 & 161 & \\
\hline 162 & 163 & 164 & 165 & 166 & 167 & 168 & \\
\hline 169 & 170 & 171 & 172 & 173 & 174 & 175 & \\
\hline 176 & 177 & 178 & 179 & 180 & 181 & 182 & \\
\hline 183 & 184 & 185 & 186 & 187 & 188 & 189 & \\
\hline 190 & 191 & 192 & 193 & 194 & 195 & 196 & \\
\hline 197 & 198 & 199 & 200 & 201 & 202 & 203 & \\
\hline 204 & 205 & 206 & 207 & 208 & 209 & 210 & \\
\hline Jumla & Jumlah & Jumlah & Jumlah & Jumlah & Jumlah & Jumlah & \\
\hline
\end{tabular}




\begin{tabular}{|c|c|c|c|c|}
\hline \multirow{2}{*}{$\begin{array}{c}\text { Aspek- } \\
\text { aspek }\end{array}$} & \multicolumn{2}{|c|}{ Ketidakstabilan emosi } & \multicolumn{2}{c|}{ Penyesuaian diri } \\
\cline { 2 - 5 } & Keterangan & Skor & Keterangan & Skor \\
\hline I & Rasa rendah diri & $6-21$ & Penghargaan diri & $22-30$ \\
\hline II & Rasa tertekan & $7-22$ & Kegembiraan & $23-30$ \\
\hline III & Kecemasan & $16-30$ & Ketabahan & $0-15$ \\
\hline IV & Keformilan & $10-25$ & Ketidakformilan & $1-9$ \\
\hline V & Ketergantungan & $5-20$ & Pengaturan diri & $21-29$ \\
\hline VI & Hypochondriasis & $6-21$ & Rasa sehat & $1-5$ \\
\hline VII & Rasa bersalah & $8-28$ & Kebebasan & $0-7$ \\
\hline
\end{tabular}




\section{(TES GAYA BELAJAR)}

\section{Berilah lingkaran pada nomor pernyataan yang anda setujui !}

1. Saya lebih suka mendengarkan informasi yang ada dikaset daripada membaca buku.

2. Jika saya mengerjakan sesuatu, saya selalu membaca instruksinya terlebih dahulu.

3. Saya lebih suka membaca daripada mendengarkan ceramah.

4. Disaat saya sendiri, saya biasanya memainkan music atau lagu atau nyanyian.

5. Saya lebih suka berolah raga daripada membaca buku.

6. Saya selalu dapat menunjukkan arah Utara dan Selatan dimanapun saya berada.

7. Saya suka menulis surat atau buku harian.

8. Saat saya berbicara, saya suka mengatakan, "saya mendengar anda, itu terdengar bagus".

9. Ruangan belajar, meja belajar, kamar tidur atau rumah saya biasanya berantakan atau tidak teratur.

10. Saya suka merancang, mengerjakan dan membuat sesuatu dengan kedua tangan saya.

11. Saya tahu hampir semua kata - kata dari lagu yang saya dengar.

12. Ketika mendengar orang lain berbicara, saya biasanya membuat gambaran dalam pikiran saya dari apa yang mereka katakan.

13. Saya suka olahraga dan saya rasa saya adalah olahragawan yang baik.

14. Mudah sekali bagi saya untuk mengobrol dalam waktu yang lama dengan teman saya saat berbicara ditelepon.

15. Tanpa music hidup amat mmbosankan.

16. Saya sangat senang berkumpul, biasanya dapat dengan mudah berbicara dengan siapa saja.

17. Saat melihat obyek dalam bentuk gambar, saya dengan mudah dapat mengenali obyek yang sama mskipun posisi obyek itu diputar atau diubah.

18. Saya biasanya mengatakan, "saya rasa, saya perlu menemukan pijakan atas hal ini, atau saya ingin bisa menangani hal ini".

19. Saat mengingat suatu pengalaman, saya seringkali melihat pengalaman itu dalam bentuk gambar dipikiran saya.

20. Saat mengingat suatu pengalaman, saya seringkali mendengar suara dan berbicara pada diri saya mengenai pengalaman itu.

21. Saat mengingat suatu pengalaman, saya seringkali ingat bagaimana perasaan saya terhadap pengalaman itu.

22. Saya lebih suka seni music daripada seni lukis.

23. Saya sering mencoret - coret kertas saat berbicara di telepon atau dalam suatu pertemuan.

24. Saya lebih suka melakukan contoh peragaan daripada membuat laporan tertulis tentang suatu kejadian.

25. Saya lebih suka membacakan cerita daripada mendengarkan cerita.

26. Saya biasanya berbicara dengan perlahan.

27. Saya lebih suka berbicara daripada menulis.

28. Tulisan tangan saya biasanya tidak rapi.

29. Saya biasanya menggunakan jari saya untuk menunjuk kalimat yang saya baca.

30. Saya dapat dengan cepat melakukan penjumlahan dan perkalian dalam pikiran saya.

31. Saya suka mengeja dan saya pikir saya pintar mengeja kata - kata.

32. Saya akan sangat terganggu apabila ada orang berbicara pada saat saya sedang menonton televise.

33. Saya suka mencatat perintah atau instruksi yang disampaikan kepada saya.

34. Saya dapat mengingat dengan mudah apa yang dikatakan orang.

35. Saya paling mudah belajar sambil mempraktekkan atua melakukan.

36. Sangat sulit bagi saya untuk duduk diam. 


\section{Penilaian:}

Hitung berapa jumlah yang anda lingkari untuk masing - masing gaya belajar.

VISUAL $: \begin{array}{llllllllllll}2 & 3 & 6 & 7 & 12 & 17 & 19 & 23 & 25 & 30 & 31 & 33\end{array}$

AUDITORIAL

$$
\begin{array}{llllllllllll}
1 & 4 & 8 & 11 & 14 & 15 & 16 & 20 & 22 & 27 & 32 & 34
\end{array}
$$

$=$

KINESTETIK
$=$

$=$

NB: Skor penilaian yang tertinggi adalah kecenderungan tipe gaya belajar anda.

(Setiap individu memiliki kecenderungan kesalah satu tipe gaya belajar, tetapi tetap ada kombinasi diantara ketiga gaya belajar tersebut).

\section{INTERPRETASI TES TIGA GAYA BELAJAR}

Terdapat tiga gaya belajar yang masing - masing memiliki ciri yang berbeda - beda. Dengan memahami gaya belajar, maka individu akan dapat menentukan langkah - langkah untuk belajar dengan lebih cepat dan mudah. Dibawah ini akan dijabarkan tentang tiga gaya belajar tersebut.

1) Gaya Belajar Visual, orang - orangnya disebut pembelajar visual.

Ciri - cirinya adalah:

a. Rapi dan teratur

b. Berbicara dengan cepat

c. Perencana dan pengatur jangka panjang yang baik

d. Teliti terhadap detail

e. Mementingkan penampilan dan tulisan

f. Pengeja yang baik dan dapat melihat kata - kata yang sebenarnya dalam pikiran mereka

g. Mengingat apa yang dilihat daripada yang didengar

h. Mengingat dengan asosiasi visual

i. Biasanya tidak terganggu oleh keributan

j. Mengalami kesulitan mengingat instruksi verbal dan cenderung minta orang mengulangi

k. Pembaca cepat dan tekun

1. Mencoret - coret tanpa arti ketika menerima telepon atau selama mengikuti pelajaran

$\mathrm{m}$. Sering lupa menyampaikan pesan verbal kepada orang lain

n. Menjawab pertanyaan dengan singkat

o. Lebih suka berdemonstrasi daripada berpidato

p. Lebih suka seni lukis, drama, tarian, dan sejenisnya daripada music

q. Seringkali tahu apa yang harus dilakukan tetapi tidak pandai memilih kata - kata.

\section{Saran bagi pembelajar visual:}

$>$ Gunakan pena dan kertas untuk membantu mengingat materi yang diterangkan guru.

Buatlah sketsa berupa diagram atau gambar - gambar dari apa yang dipelajari.

$>$ Warnai teks yang penting saat membaca dengan menggunakan spidol berwarna cerah.

$>$ Gunakan imajinasi visualpikiran saat mencermati materi, dengan cara menutup mata untuk menvisualisasikan atau mengingat sesuatu. 
Belajar membaca terbalik ( up side down). Peneliti menemukan; melakukan kegiatan normal dengan cara aneh, seperti membaca terbalik, akan membuat pikiran anda tajam.

(lakukan kegiatan ini \pm 1 menit sebelum memulai kegiatan belajar).

2) Gaya Belajar Auditorial, orang - orangnya disebut pembelajar auditorial.

Ciri - cirinya adalah:

a. Sering berbicara pada diri sendiri saat belajar

b. Mudah terganggu oleh keributan

c. Menggerakkan bibir dan mengucap tulisan dibuku ketika membaca

d. Senang mendengar dan membaca dengan suara keras

e. Mampu mengulangi dan menirukan nada dan suara

f. Kesulitan dalam mnulis tetapi pandai dalam bercerita

g. Berbicara dengan irama yang berpola

h. Biasanya merupakan pembicara yang fasih

i. Lebih suka music dan belajar sambil mendengarkan music

j. Belajar dengan mendengarkan dan mengingat apa yang didiskusikan

k. Suka berbicara, berdiskusi dan menjelaskan sesuatu dengan panjang lebar

1. Kesulitan dalam pekerjaan yang melibatkan visualisasi seperti memotong bagian - bagian hingga sesuai satu sama lain

m. Lebih pandai mengeja dengan keras daripada menuliskannya

n. Lebih suka gurauan lisan daripada cerita lucu dari komik.

\section{Saran bagi pembelajar auditorial:}

> Saat membaca materi, suarakan materi tersebut dalam hati untuk mengingatnya.

$>$ Gunakan kaset rekaman saat guru menerangkan dikelas sehingga dirumah dapat diputar dan dipelajari kembali.

> Belajar bersama teman dengan cara berdiskusi atau Tanya jawab.

> Saat belajar, luangkan waktu untuk melakukan diskusi internal tentang materi yang diberikan.

Konsentrasikan saja pada penjelasan guru karena pembelajar ini cocok dengan metode ceramah. (duduk dimana anda dapat mendengar tapi tidak perlu memperhatikan apa yang terjadi didepan).

Duduk dengan tenang, tutup mata dan dengar satu suara. Suara itu mungkin saja bunyi derap langkah kaki yang lewat, mobil lewat, kicau burung atau kokok ayam atau suara yang lain. Jangan hiraukan pada suara - suara yang lain. Itu akan menambah konsentrasi dan membuat anda menyelesaikan tugas - tugas yang rumit lebih cepat.

(lakukan kegiatan ini \pm 1 menit sebelum memulai kegiatan belajar).

3) Gaya Belajar Kinestetik, orang - orangnya disebut pembelajar kinestetik.

Ciri - cirinya adalah:

a. Berbicara dengan perlahan

b. Menanggapi perhatian fisik

c. Menyentuh orang untuk menarik perhatian mereka

d. Berdiri dekat ketika berbicara dengan orang

e. Beroirentasi pada fisik dan senang bergerak

f. Belajar melalui praktek

g. Menghafal dengan cara berjalan dan melihat - lihat

h. Menggunakan jari sebagai petunjuk ketika membaca

i. Banyak menggunakan isyarat tubuh 
j. Tidak dapat duduk dalam waktu lama

k. Menggunakan kata - kata yang mengandung aksi

1. Membaca dengan menyertakan gerakan fisik sesuai dengan isi cerita

m. Kemungkinan tulisannya jelek

n. Selalu ingin mempraktekkan segala sesuatu

o. Suka permainan yang menyibukkan.

\section{Saran bagi pembelajar kinestetik:}

> Tempat diri di lingkungan yang aktif, materi yang didiskusikan dengan disertai simulasi (praktek) lebih mudah diserap dengan baik.

Tandai materi yang penting dengan spidol warna.

$>$ Buatlah catatan peta yaitu catatan dengan disertai gambar sehingga selama pembelajaran kegiatan kinestetik terus berlangsung.

> Peragakan atau praktekkan materi yang dipelajari.

$>$ Tarik nafas selama 10 detik. Itu akan membuat otak dibanjiri oksigen, membantu anda berpikir lebih cepat. (lakukan kegiatan ini sebelum memulai kegiatan belajar).

Rutinkan olahraga. Melalui olahraga kimiawi perasaan - baik, endorphins, makin terpacu keluar, yang dapat membuat kepala kita tidak penat.

Catatan: dari ketiga gaya belajar tersebut, individu juga ada yang memiliki lebih dari satu gaya belajar (kombinasi), missal; visual - auditori, auditori - kinestetik, atau visual - kinestetik. Disarankan menggunakan teknik belajar yang sesuai kombinasi dari masing - masing gaya belajarnya. Selain penting untuk mengetahui gaya belajar sendiri juga untuk memahami gaya belajar orang lain sehingga tidak terjadi benturan karena adanya perbedaan tetapi masing - masing individu tetap dapat berkomunikasi dengan saling menyesuaikan diri satu sama lain. 


\section{ANGKET BERPIKIR POSITIF}

\section{PETUNJUK :}

Berilah tanda $(\sqrt{ })$ pada jawaban yang tersedia !

1. Ada orang - orang yang jauh lebih baik daripada saya.
Ya
Tidak

2. Saya selalu ingin agar segala sesuatunya di kerjakan dengan cara saya.

Ya

Tidak

3. Saya benar - benar percaya bahwa kesan pertama adalah kesan terakhir.
Ya
Tidak

4. Saya tidak membuat keputusan yang tergesa - gesa.
Ya
Tidak

5. Saya tidak yakin dengan kemampuan saya.
Ya
Tidak

6. Saya menyambut baik kritik yang sehat dari orang lain. Ya

Tidak

7. Saya tidak pernah mengucapkan hal - hal yang menyakitkan.
Ya
Tidak

8. Saya di kenal sering melontarkan lelucon yang mengorbankan orang lain.
Ya
Tidak

9. Saya mengharap bahwa saya lebih cantik.
Ya
Tidak

10. Saya dengan sabar mendengarkan bila orang lain sedang berbicara.
Ya
Tidak

11. Hampir semua persoalan saya tampaknya tidak ada solusinya.
Ya
Tidak

12. Pikiran saya bebas dari pikiran yang merusak.

Ya $\square$ Tidak

13. Peluang yang hilang tidak akan datang lagi.

Ya

Tidak

14. Saya berterus terang dengan jujur.

Ya

Tidak

15. Kreativitas hanya dimiliki pembangun gedung, pengembang perumahan, dan seniman. Ya $\square \quad$ Tidak

16. Saya selalu percaya bahwa saya sangat dibutuhkan.

Ya

Tidak

17. Saya menilai tinggi diri saya sendiri.
Ya
Tidak

18. Saya menghormati manusia dari semua kelas social.
Ya
Tidak

19. Saya selalu benar dalam perkataan dan perbuatan saya.
Ya
Tidak

20. Saya suka menerima tantangan baru.

$$
\text { Ya }
$$

Tidak

21. Saya mempercayai semua keputusan yang saya ambil.

$$
\text { Ya }
$$

Tidak 
22. Saya tidak suka untuk memikul tanggung jawab tambahan.

$$
\text { Ya } \square \quad \text { Tidak }
$$

23. Membuat alasan yang mengada adalah seni yang tidak semua orang bisa menguasai.

$$
\text { Ya }
$$$$
\text { Tidak }
$$

24. Saya selalu berpikir dua kali sebelum saya bertindak.
Ya
Tidak

25. Saya selalu berbicara poitif tentang diri saya sendiri.
Ya
Tidak

26. Saya selalu berbicara positif tentang orang - orang lain.

$$
\text { Ya } \square \quad \text { Tidak }
$$

27. Pikiran saya tunduk pada perasaan saya.
Ya
Tidak

28. Tak banyak hal baik yang dapat saya katakan tentang diri saya seniri.
Ya
Tidak

29. Saya dapat mencapai apa yang saya inginkn.

$$
\text { Ya } \square \quad \text { Tidak }
$$

30. Hampir semua upaya pantas di hargai dengan positif.

$$
\text { Ya } \square \quad \text { Tidak }
$$

31. menerima kritik dengan anggun adalah kunci kesuksesan.

Ya

Tidak

32. saya mengeluh ketika segala sesuatunya dikerjakan tidak sesuai dengan keinginan saya. Ya

Tidak 


\section{TES KECERDASAN MAJEMUK}

Bacalah dengan sebaik-baiknya dan teliti tiap-tiap pernyataan, kemudian berilah tanda silang (X) pada nomor pernyataan yang sesuai dengan keadaan anda pada lembar jawaban yang tersedia dibawah! Kerjakan dengan teliti!!!

\section{A. KECERDASAN LINGUISTIK}

1. Sangat menyukai pelajaran bahasa Indonesia

2.Senang menulis atau mengarang

3. Senang bercerita panjang lebar atau menyampaikan kisah-kisah

4.Pandai berkomunikasi dengan ekspresi yang bagus

5.Menyukai puisi, pantun, dan drama

6.Suka mendengarkan pernyataan-pernyataan lisan, (cerita, ulasan radio, dll)

7. Memiliki kosa kata yang baik

8. Senang membaca buku

9. Senang mengingat nama, tanggal, dan tempat

10. Senang dengan game permainan kata

\section{B. KECERDASAN MATEMATIKA LOGIS}

1.Sangat senang dengan pelajaran matematika

2.Senang bermain dengan angka-angka

3. Senang mengerjakan teka-teki logika atau soal-soal yang sulit

4. Senang melakukan percobaan (tertarik pada teknologi)

5.Senang menganalisa situasi atau argumentasi

6. Senang bekerja secara sistematis

7. Senang pada suatu yang membutuhkan kemampuan berfikir logis

8. Menganggap game matematika dan komputer menarik

9.Menunjukkan minat pada mata pelajaran yang berhubungan dengan sains (IPA)

10. Senang permainan catur, dam, atau game strategi lain.

\section{KECERDASAN SPASIAL}

1. Senang menggambar atau melukis

2. Senang dengan kegiatan seni

3.Lebih mudah bekerja dengan gambar dari pada dengan teks

4.Lebih mudah membaca peta, diagram, dan grafik

5.Senang merancang konstruksi bangunan, bentuk, ruang, dekorasi, dan interior

6.Senang dengan pelajaran keterampilan

7. Senang melihat film, slide, atau kegiatan visual sejenis

8. Senang melamun, berkhayal, membaca cerita imajinatif

9. Senang mengabadikan gambar

10. Dapat melaporkan bayangan visual dengan jelas

\section{KECERDASAN KINESTETIK JASMANI}

1.Menonjol disalah satu atau lebih dicabang olah raga

2. Selalu bergerak, tidak bisa diam, atau selalu gelisah ketika duduk lama di suatu tempat

3. Senang berlari, melompat, gulat, atau kegiatan semacamnya

4.Senang dengan kegiatan menari, atau kegiatan yang membutuhkan gerak tubuh

5.Pandai meniru gerak isyarat atau tingkah laku orang lain

6. Senang membongkar pasang barang

7. Menunjukkan kemahiran dalam bidang keterampilan, misal: pertukangan, menjahit, dsb.

8. Senang bekerja dengan tanah liat, atau pengalaman yang melibatkan sentuhan tangan

9.Lebih senang mempelajari hal baru langsung dengan praktek

10. Mampu mengekspresikan diri secara dramatis 
E. KECERDASAN MUSIKAL

1.Senang pada pelajaran musik dan seni suara

2.Pandai menyanyi dengan suara merdu

3.Dapat menunjukkan nada yang sumbang

4.Dapat memainkan alat musik

5. Sering bersenandung tanpa sadar

6. Bersemangat ketika musik dimainkan

7.Dapat mengingat melodi lagu atau irama dengan cepat

8.Peka pada bunyi-bunyian disekitar

9. Mengetuk-ngetuk meja saat bekerja

10. Memiliki cara berbicara dan bergerak yang berirama

\section{F. KECERDASAN INTERPERSONAL}

1. Senang bersosialisasi dengan teman sebaya

2.Mudah menyesuaikan diri dengan lingkungan yang baru

3. Mudah bergaul

4.Mempunyai banyak teman

5.Banyak disukai teman

6. Senang memberi saran pada teman yang mempunyai masalah

7. Senang benjadi pemimpin

8. Senang menjadi anggota club, panitia, atau kelompok informal diantara teman sebaya

9. Senang mengajari anak-anak lain secara informal

10. Mempunyai empati atau perhatian pada orang lain

\section{G. KECERDASAN INTRAPERSONAL}

1.Sangat menyenangi pelajaran agama dan pelajaran budi pekerti

2.Menunjukkan sikap mandiri

3.Memahami dengan baik kekurangan dan kelebihan diri

4.Memiliki perencanaan diri yang baik

5.Mampu belajar dari kegagalan dan keberhasilan yang dialami

6.Lebih senang dengan bekerja sendiri dari pada bekerja dengan orang lain

7.Mampu menyelami dan mengerti kerumitan pribadi dan kondisi manusia pada umumnya

8. Dapat mengekspresikan perasaan secara tepat

9. Memiliki gaya hidup dan gaya belajar dengan irama sendiri

10. Memiliki minat dan hobi yang jarang dibicarakan

\section{H. KECERDASAN NATURALIS}

1.Sangat senang pada pelajaran biologi atau IPA

2.Peka pada bentuk-bentuk alam, misalnya ketika berjalan-jalan dengan teman sekelas akan memperhatikan gunung-gunung, awan-awan, atau jika dalam lingkungan perkotaan kemampuannya ditunjukkan dengan kepekaan pada bentuk-bentuk budaya populer, seperti model sepatu, karet, atau model mobil

3. Berbicara banyak tentang binatang kesayangannya atau lokasi-lokasi alam favorit

4. Senang memelihara binatang

5. Senang merawat tanaman

6. Senang karya wisata dialam, kebun binatang, atau ke musium purbakala

7. Senang melakukan penelitian yang berhubungan dengan alam, misalnya mengamati burung, mengumpulkan serangga atau kupu-kupu atau mempelajari tanaman-tanaman

8. Senang mempelajari tentang dunia antariksa

9. Suka menggunakan peralatan seperti: mikroskop, telekskop, komputer untuk mempelajari suatu organisme atau sistem

10. Senang menyerukan hak binatang atau perlunya melindungi planet bumi atau melestarikan alam. 


\section{LEMBAR JAWABAN}

\section{TES KECEDASAN MAJEMUK}

Berilah tanda silang $(X)$ sesuai pernyataan diatas sesuai keadaan anda pada lembar jawaban yang tersedia dibawah ini ! kerjakan dengan teliti !!!

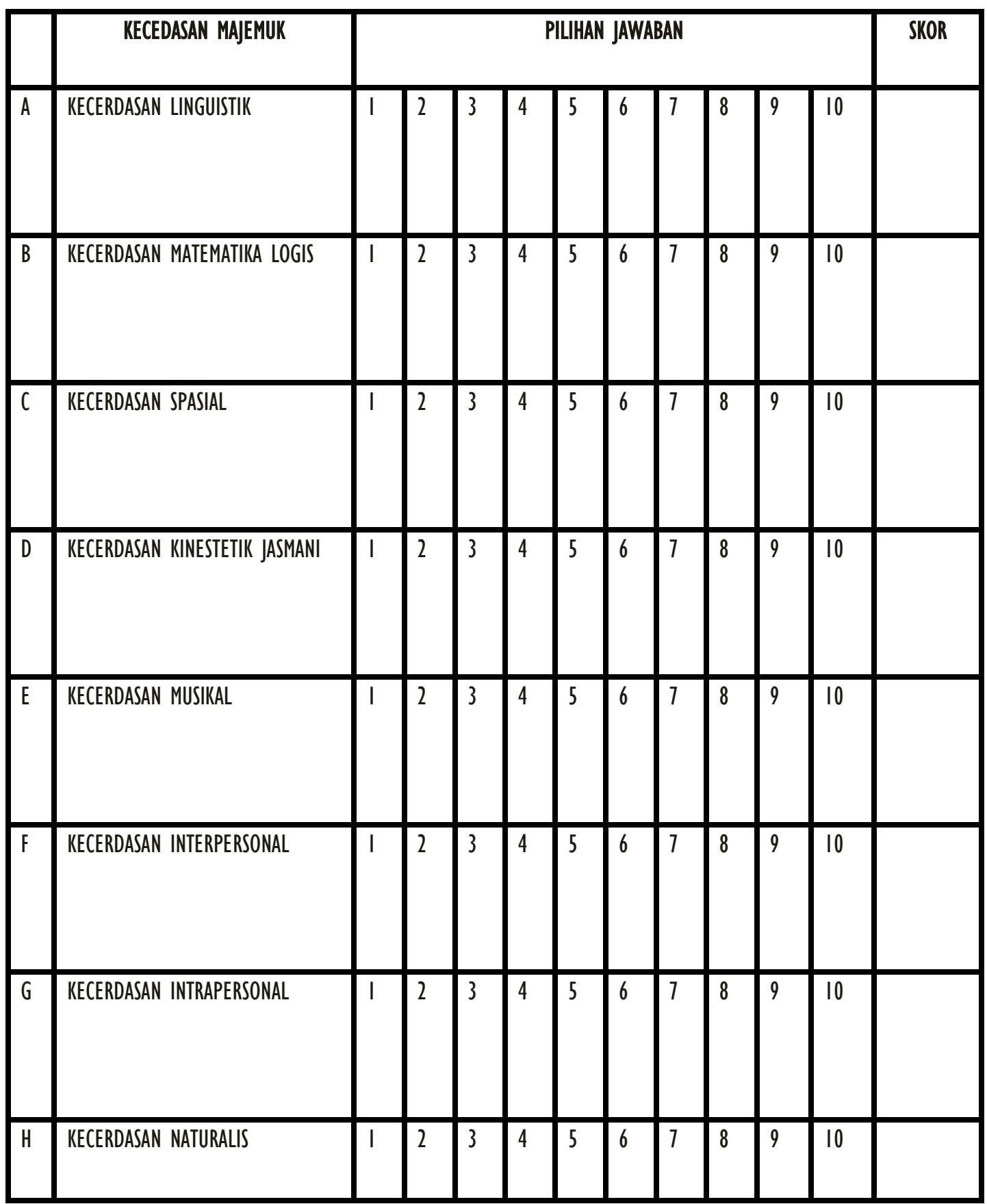




\section{Daftar Pustaka}

Ahmad Juntika Nurihsan. 2005. Strategi layanan Bimbingan dan Konseling. Bandung: PT.Refika Aditama.

Ali, O.M., Milstein, G., dan Marzuk, P.M. 2011. "The Imam's Role in Meeting the Counseling Needs of Muslim Communities in the United States". Psychiatric Services, Februari 2005 Vo. 56

Arlhouns, J.F. 1995. Psikologi Tentang Penyesuaian dan Hubungan kemanusiaan (Terjemaham R.S. Satmoko). Semarang: IKIP Press.

Asosiasi Bimbingan dan Konseling Indonesia. 2007. Penataan Pendidikan Profesional Konselor. Naskah Akademik ABKIN

Fahyuni, Eni Fariyatul \& Istikomah, 2016. Psikologi Belajar Mengajar (Kunci Sukses Guru dan Peserta Didik dalam Interaksi Sosial). Sidoarjo: Nizamia Learning Center.

Fahyuni, Eni Fariyatul. \& Bandono, Adi. Pengembangan Media Cerita Bergambar Sebagai Upaya Meningkatkan Kemampuan Membaca Siswa Sekolah Dasar. Halaqa: Jurnal Kependidikan dan KeislamanVol 14. No. 1. April 2015.75-89

Fahyuni, Eni Fariyatul. \& Bandono, Adi. The use of value clarification technique-basedpicture story media as an alternative media to value education in primary school. HARMONIA: Journal of Arts Research and Education 17 (1) (2017), 68-74

Fahyuni, Eni Fariyatul. \& Fauji, Imam. Pengembangan Komik Akidah Akhlak untuk Meningkatkan Minat Baca dan Prestasi Belajar Siswa Sekolah Dasar. Halaqa: Islamic Education Journal 1 (1), Juni 2017, 17-26

Fahyuni, Eni Fariyatul. (2017). Teknologi, Informasi, dan Komunikasi (Prinsip dan Aplikasi dalam Studi Pemikiran Islam). Sidoarjo: Umsida Press.

Hadi. 2013. Pemahaman konsep sekolah tentang tugas perkembangan siswa dan layanan yang diberikan. Jakarta: Jurnal Ilmiah Konseling. Vol. 2, No. 1

Hallen A. 2002. Bimbingan dan Konseling Islam, Jakarta: Ciputat Press.

Kamaluddin. Bimbingan dan Konseling Sekolah. Jakarta: Jurnal: Pendidikan dan Kebudayaan. Vol. 17 No.4

Kartadinata, S, dkk. (1998). Bimbingan di Sekolah Dasar. Direktorat Jenderal Pendidikan Tinggi. Departemen Pendidikan dan Kebudayaan.

Menteri Pendidikan Nasional. 2006. Peraturan Menteri Nomor 22 tentang Standar Isi untuk Satuan Pendidikan Dasar dan Menengah. Jakarta: Departemen Pendidikan Nasional 
Mu'awanah, E. dan Hidayah, R. 2009. Bimbingan dan Konseling Islami di Sekolah Dasar. Jakarta: Bumi Aksara.

Nurdyansyah., \& Fahyuni, E.F. 2016. Inovasi Model Pembelajaran Sesuai Kurikulum 2013. Sidoarjo: Nizamia Learning.

Nurihsan, Achmad Juntika. 2005. Strategi Layanan Bimbingan dan Konseling. Bandung: PT Refika Aditam.

Nursalim, Mochammad dan Suradi SA. 2002. Layanan Bimbingan dan Konseling. Surabaya: UNESA University Press

Prayitno \& Amti, E. (2013). Dasar-dasar bimbingan dan konseling (cet. 3). Jakarta: Rineka Cipta.

Siregar. 2013. Peranan Bimbingan dan Konseling dalam mengatasi masalah belajar siswa. Jakarta: logaritma. Vol. 1 No. 1

Sukardi., Drs. Dewa Ketut, Dasar-dasar Bimbingan dan Penyuluhan di Sekolah, Penerbit Usaha Nasional, Surabaya, Cet.III 1985

Walgito, B. 2005. Bimbingan dan Konseling (Studi dan Karir). Yogyakarta: Andi 


\section{BIODATA PENULIS}

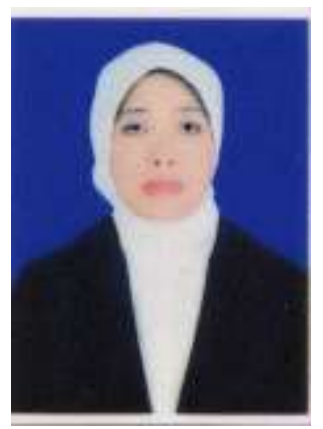

Eni Fariyatul Fahyuni merupakan seorang dosen di Fakultas Agama Islam, Universitas Muhammadiyah Sidoarjo yang mengampu beberapa mata kuliah diantaranya: profesi keguruan, ilmu kependidikan, bimbingan dan konseling, psikologi perkembangan, psikologi belajar, Kapita Selekta Pendidikan dan ICT pembelajaran. Putri ke-3 dari pasangan bapak H. Ach. Fithon dan Ibu Hj. Ismachu Djumroh ini lahir di Sidoarjo, 04 November 1978 yang mengawali kariernya sebagai konselor bimbingan dan konseling di SMK pada tahun 2011 hingga tahun 2014. Buku hasil karya yang sukses diterbitkan antara lain 1) Tahun 2016, buku Inovasi Model Pembelajaran Sesuai Kurikulum 2013; 2) Tahun 2016, buku Psikologi Belajar dan Mengajar (Kunci Sukses Guru dan Peserta Didik dalam Interaksi Edukatif); 3) Tahun 2017, buku Teknologi Informasi dan Komunikasi (Prinsip dan Aplikasi dalam Studi Pemikiran Islam), 4) tahun 2018, Kenapa Bisa Begini, Ya? Suhu dan Kalor, dan 5) Tahun 2018, buku ajar "Senangnya Bisa Bersedekah". Latar belakang pendidikan yang digelutinya adalah sarjana Universitas Islam Negeri Sunan Ampel Surabaya Program Studi Psikologi (2011) selanjutnya Pendidikan Islam Pascasarjana Universitas Muhammadiyah Sidoarjo (2013), dan saat ini penulis sedang menempuh studi Doktoral Program Studi Teknologi Pendidikan di Universitas Negeri Surabaya (UNESA). 